\title{
5. LATE PALEOGENE DIATOM BIOSTRATIGRAPHY AND PALEOENVIRONMENTS OF THE NORTHERN NORWEGIAN-GREENLAND SEA ${ }^{1}$
}

\author{
Reed P. Scherer ${ }^{2}$ and Nalân Koç ${ }^{3}$
}

\begin{abstract}
Diatom occurrence, abundance, and biostratigraphic position are documented from Paleogene sediments of Ocean Drilling Program (ODP) Leg 151 in the high-latitude Norwegian-Greenland Sea. Previous ocean drilling in the Norwegian-Greenland Sea (ODP Leg 104, Deep Sea Drilling Project [DSDP] Leg 38) provided incomplete Paleogene sections. Paleogene sediments recovered as part of ODP Leg 151 contribute toward a regional composite stratigraphic section, although significant gaps remain. The Paleogene diatom assemblages of Leg 151 differ from those previously recovered, thereby contributing to the development of a regional diatom biostratigraphic zonal scheme. Biosiliceous upper Paleogene sediments were recovered from Hole 908A in the Fram Strait and Hole 913B along the northeast Greenland Margin. Hole 908A contains an upper lower to lower upper Oligocene diatom assemblage dominated by resting spores and other diatoms that suggest high productivity in a neritic setting. The youngest diatom assemblage present in the sequence approximates the oldest Oligocene diatom assemblage of DSDP Leg 38, Site 338, of the Sceptroneis pupa Zone. Conformably beneath the $S$. pupa Zone in Hole 908A is the upper lower Oligocene Sceptroneis fennerae Zone, which is defined in this study. The Cymatosira praecompacta Zone, defined here, conformably underlies the $S$. fennerae Zone. Hole 913B contains biosiliceous successions containing a diatom assemblage with an upper upper Eocene character but also including lower lower Oligocene elements. This assemblage defines the Actinoptychus irregularis Zone, established here, which resembles biosiliceous sediments recovered at Site 339 of DSDP Leg 38. The lowermost in situ diatoms recovered include an assemblage of middle Eocene pyritized forms in Hole 913B. Reworked lower Paleogene diatoms occur in upper Paleogene sediments of Sites 908 and 913 and in Pliocene and Quaternary glacially influenced sediments, particularly those of the Yermak Plateau (Sites 910, 911, and 912). Two new species are described, Sceptroneis fennerae $\mathrm{n}$. sp. and Thalassiosira nansenii $\mathrm{n}$. sp. T. nansenii formally names the widely distributed high-latitude diatom previously known as Thalassiosira affn. irregulata. Rhizosolenia oligocaenica var. styliforma $\mathrm{n}$. var. and Sceptroneis humuncia var. rondipoda $\mathrm{n}$. var. are also defined.
\end{abstract}

\section{INTRODUCTION}

\section{Leg 151 Biosiliceous Paleogene}

This paper reports on the occurrence, abundance, and biostratigraphic position of diatoms in Paleogene sediments recovered during Ocean Drilling Program (ODP) Leg 151 in the northern NorwegianGreenland Sea (Fig. 1). These assemblages are used to interpret depositional environments, with regard to paleoproductivity and proximity to a paleoshoreline, and syndepositional and postdepositional bottom-water conditions. Upper Paleogene biosiliceous sediments were recovered from two sites in the northern Norwegian-Greenland Sea during ODP Leg 151 (Fig. 1). Site 908 was drilled on the Hovgaard Ridge in the Fram Strait at $78^{\circ} 23.1^{\prime} \mathrm{N}, 1^{\circ} 21.6^{\prime} \mathrm{E}$, in $1273 \mathrm{~m}$ of water. Lower upper to upper lower Oligocene biosiliceous sediments were recovered. Site 913 was drilled along the East Greenland Margin at $75^{\circ} 29.4^{\prime} \mathrm{N}, 6^{\circ} 56.8^{\prime} \mathrm{E}$, in $3318 \mathrm{~m}$ of water. Biosiliceous sediments were recovered that represent sedimentation very close to the Eocene/Oligocene boundary. Unfortunately, biostratigraphy in this interval is equivocal, and, thus far, independent dating of the recovered sections by magnetostratigraphy and radiometric methods has also proven problematic. The best estimate available suggests that the Eocene/Oligocene boundary was recovered in the biosiliceous interval of Hole 913B, between Sections 151-913B-24R-2 and 27R-5. The boundary is recognized by different microfossil groups at differ-

'Thiede, J., Myhre, A.M., Firth, J.V., Johnson, G.L., and Ruddiman, W.F. (Eds.), 1996. Proc. ODP, Sci. Results, 151: College Station, TX (Ocean Drilling Program).

${ }^{2}$ Institute of Earth Sciences, Uppsala University, Norbyvägen 18B, S-752 36 Uppsala, Sweden, Reed.Scherer@ natgeog.uu.se

${ }^{3}$ Department of Geology, University of Bergen, Allégaten 41, N-5007 Bergen, Nor- ent places within this interval, but the boundaries, as recognized by siliceous, calcareous, and organic-walled microfossils, are not confi-

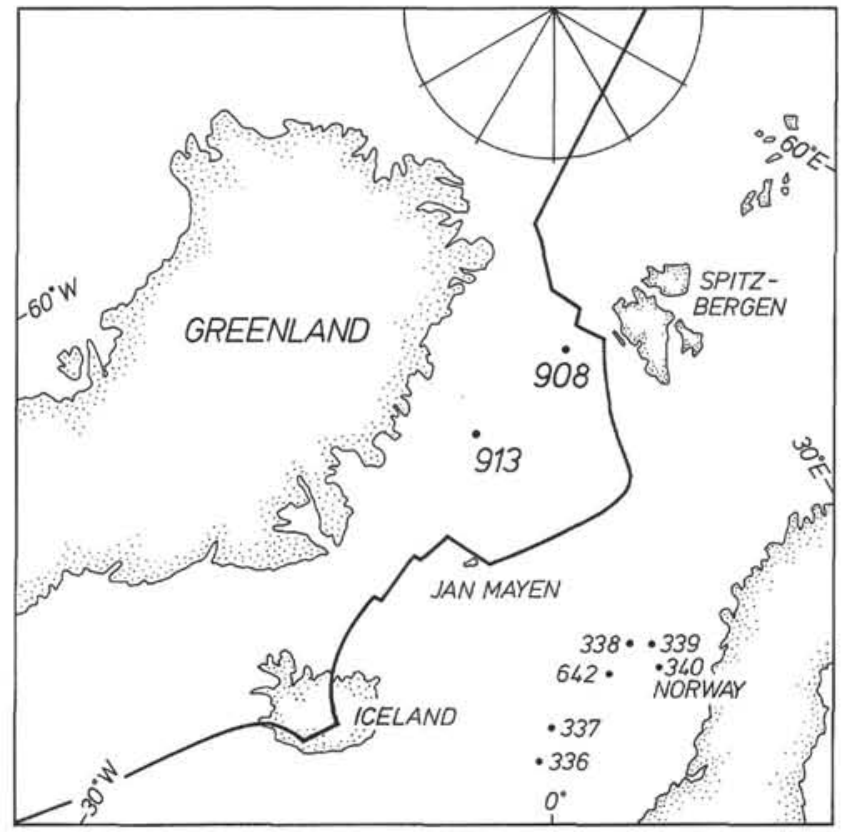

Figure 1. Location of Leg 151 Sites 908 and 913 in the NorwegianGreenland Sea. Also shown are drill sites in the Norwegian-Greenland Sea from DSDP Leg 38 and ODP Leg 104 that contained biosiliceous Paleogene sediments. 
dently drawn. This is due, in part, to biostratigraphic uncertainties in the high latitudes, but also because the "boundaries" tend to fall at some kind of lithologic transition. Consequently, the biosiliceous interval 151-913B-24R-2 through 27R-5 may be all or in part within eiti. $r$ epoch. For further discussion, see the chronostratigraphic summary chapter (Hull et al., this volume) for ODP Leg 151. Biostratigraphic and paleoceanographic analyses of diatoms in Neogene sediments of Leg 151 can be found in Koç and Scherer (this volume).

\section{Late Eocene-Early Oligocene Paleoceanography}

The late Paleogene was an interval of major climatic and oceanographic reorganization, characterized by the transition from warm Eocene to cold Oligocene conditions. Oxygen and carbon isotopic records across the Eocene-Oligocene transition suggest major changes in bottom-water exchange. Eocene bottom-water conditions are generally believed to have been warm, oxygenated, and relatively sluggish (Miller, 1994; Miller and Tucholke, 1983; Moore et al., 1978). Major changes in bottom-water production occurred in the earliest Oligocene, leading to the formation of widespread deep-sea hiatuses (Moore et al., 1978). Oxygen isotopes across this transition show significant cooling of bottom waters, and carbon isotopes suggest changing bottom-water sources (Miller, 1994). Bottom waters were being produced at both poles during a brief period in the early early Oligocene and exchanged throughout the global ocean (Miller, 1994).

The late Eocene and early Oligocene are notoriously difficult intervals to study because the invigoration of bottom waters led to the development of widespread deep-sea hiatuses (Moore et al., 1978). The Norwegian-Greenland Sea was the conduit for Arctic-produced bottom waters during the "pulse" of Northern Component Water documented by Miller (1994). Consequently, the Norwegian-Greenland Sea should be one of the key basins for study of Paleogene oceanic paleocirculation. Although Eocene and Oligocene sediments have been recovered during previous drilling in the Norwegian-Greenland Sea, an Eocene/Oligocene boundary section was not recovered.

These bottom-water events marked the beginnings of modern oceanic circulation. The most significant climatic event that followed was the establishment of extensive continental glaciation in East Antarctica (Barron et al., 1989). Accumulation of diatomaceous sediments, and the diatom assemblages contained therein, was also directly affected by changes in ocean circulation. Siliceous productivity surged in the Southern Ocean in the early Oligocene following this event (Baldauf, 1994; Baldauf and Barron, 1991; Harwood and Maruyama, 1992). There was a similar, though less dramatic, response in the early early Oligocene in the North Atlantic/Labrador Sea region (Baldauf, 1994; Baldauf and Monjanel, 1989).

Global diatom taxonomic overturn (first and last occurrences) across the Eocene/Oligocene boundary has been estimated to be as high as $45 \%$ (Fenner, 1985; 1986; Baldauf, 1994), indicating that there was not only an increase in productivity, but also a rapid speciation and extinction rate at this time. However, biosiliceous reference sections that include an Eocene/Oligocene boundary are scarce, particularly in the high latitudes. Previous drilling in the NorwegianGreenland Sea has recovered considerable middle Eocene sediments (Sites 338 and 340) and a rather good upper Oligocene section (Site 338). Only rare and poorly dated upper Eocene? (Site 339) and lower Oligocene? sections (Site 336, Site 337, and Site 642) were recovered (Fenner, 1985; Dzinoridze et al., 1978; Schrader and Fenner, 1976, Eldholm, Thiede, Taylor, et al. 1987; Myhre, Thiede, Firth, et al., 1995). None of these sections has been reliably tied to magnetostratigraphy, and few have good cross-correlation with calcareous nannofossil stratigraphy; thus, their exact chronostratigraphic positions remain uncertain. ODP Leg 151 sediments include a biosiliceous interval that approximates the Eocene/Oligocene boundary
(Hole 913B), but this interval also lacks good independent chronostratigraphic control.

\section{METHODS}

In order to gauge diatom abundance and preservation as accurately as possible, as well as to target the best samples for detailed biostratigraphic analysis, smear slides for diatom analysis were prepared from more than 200 stratigraphic positions within the diatom-bearing Paleogene sediments. Material was mechanically disaggregated in deionized water, spread across a $22-x-40-m m$ cover glass, and mounted in Norland optical adhesive. Smear slides provide an unaltered and unbiased representation of the original assemblage, provided that diatoms are not diluted with significant abundance of finegrained carbonate.

Selected samples were prepared using the method described by Baldauf and Monjanel (1989), when possible. However, the nature of these sediments made standard diatom preparation procedures difficult or impossible. Furthermore, attempts at preparation of slides for quantitative analysis of the diatom assemblage, using the method of Scherer (1994), proved unsatisfactory. The difficulties came about because the sediments are partially cemented with an altered organic matrix, which makes disaggregation of the particles by chemical means very difficult without damaging fine siliceous structures. Most samples are devoid of carbonate and contain a high enough abundance of diatoms to make smear slide analysis sufficient for biostratigraphic purposes. Certain samples contain rare diatoms replaced by pyrite, in an unconsolidated and very clay-rich matrix. Oxidizers such as hydrogen peroxide destroy such fossil remains, but surfactants, such as sodium hexametaphosphate cause no damage. Pyritized diatoms, silicoflagellates, and ebridians were concentrated using a $20-\mu \mathrm{m}$ mesh sieve. This biases the assemblage against the smallest diatoms, but the high abundance of clay made concentration of diatom debris by other methods impracticable.

Diatom total and relative abundance was estimated from smear slides observed at $600 \times$ magnification $(60 \times$ oil objective) on an Olympus BX50 interference contrast microscope. Diatom abundance was initially estimated by percentage, based on standard ODP smear slide guidelines, and recorded on a 10-step scale. These numerical estimates were then reduced to qualitative abundance categories following an approximate logarithmic scale. The abundance categories are defined in Table 1A. The relative abundance of each diatom taxon, as reported in the range charts, is estimated based on the qualitative scale described in Table 1B. Diatom preservation categories reported in the range charts are described in Table 1C.

Diatom identification was performed utilizing original references and figures whenever possible, in addition to modern references. Several genera and morphologic groups are tabulated as groups, at the generic level, despite apparent species-level diversity. This approach applies most often to resting spores. Generic identifications generally follow Round et al. (1990). Certain described species or species complexes do not fit the generic descriptions for their assigned genera. If an appropriate alternative genus is not known or has not been described, the original genus is retained but the genus name is placed in quotes to indicate that a taxonomic problem exists at the generic level (e.g., "Rhizosolenia" pokrovskayae).

\section{NORWEGIAN-GREENLAND SEA DIATOM ZONATION}

Biostratigraphic interpretation of the Paleogene diatom assemblages from Leg 151 comes largely by comparison with diatom assemblages of the Norwegian-Greenland Sea (Schrader and Fenner, 
Table 1. Diatom abundance and preservation categories.

1A. Definition of categories for total diatom abundance (Tables 2-5)

\begin{tabular}{|c|c|c|}
\hline $\begin{array}{l}\text { Abundance } \\
\text { category }\end{array}$ & Descriptor & Definition \\
\hline 1 & B (barren) & No diatom debris evident \\
\hline $2-3$ & $\mathrm{R}$ (rare) & Trace quantitities to $\sim 2 \%$ diatoms \\
\hline $4-5$ & $F($ few) & $-2 \%$ to $\sim 5 \%$ diatoms \\
\hline $6-7$ & $\mathrm{C}$ (common) & $-5 \%$ to $-20 \%$ diatoms \\
\hline $8-9$ & A (abundant) & $\sim 20 \%$ to $\sim 60 \%$ diatoms \\
\hline 10 & $\mathrm{M}$ (mass) & $>60 \%$ diatoms \\
\hline \multicolumn{3}{|c|}{ 1B. Categories for relative abundance of individual taxa (Tables 3,5 ) } \\
\hline & M & $\begin{array}{l}\text { Nearly monospecific diatom assemblage of } \\
\text { mass abundance }\end{array}$ \\
\hline & A & 2 or more specimens per field of view \\
\hline & C & $1-5$ specimens per 5 fields of view \\
\hline & $\mathrm{F}$ & $1-5$ specimens per horizontal transect $(40 \mathrm{~mm})$ \\
\hline & $\mathrm{R}$ & Fewer than 1 specimen per transect \\
\hline & $\mathrm{r}$ & Rare, reworked \\
\hline \multicolumn{3}{|c|}{ 1C. Diatom preservation categories (Tables 3,5 ) } \\
\hline & G (good) & $\begin{array}{l}\text { Finely silicified and robust forms present, no } \\
\text { significant alteration of the frustules, other } \\
\text { than moderate fragmentation }\end{array}$ \\
\hline & M (moderate) & $\begin{array}{l}\text { Concentration of more heavily silicified forms } \\
\text { and/or a high degree of fragmentation of } \\
\text { finely silicified forms }\end{array}$ \\
\hline & $\mathrm{P}$ (poor) & $\begin{array}{l}\text { Finely silicified forms virtually absent, heavily } \\
\text { silicified forms fragmented and/or corroded }\end{array}$ \\
\hline
\end{tabular}

1976; Dzinoridze et al., 1978; Fenner, 1985), the North Atlantic and Labrador Sea (Baldauf and Monjanel, 1989), the northwest Pacific region (Baldauf and Barron, 1987; Yanagisawa and Suzuki, 1987), and the antarctic offshore (including Harwood and Maruyama, 1992; Baldauf and Barron, 1991; Fenner, 1978, 1984; Gombos, 1983; Gombos and Ciesielski, 1983; Schrader, 1976; Hajós, 1976) and nearshore zones (Barron and Mahood, 1993; Harwood, 1989; Harwood et al., 1989). Many of the low-latitude biostratigraphic markers are very rare or are absent from the high latitudes; nevertheless, published studies of lower latitude Paleogene diatom assemblages, including those described by Palmer (1984), provide worthwhile comparison, particularly for the oldest diatom assemblages of Leg 151.

The Norwegian-Greenland Sea diatom zonation of Fenner (1985) builds on the best elements of previous zonations of Schrader and Fenner (1976) and Dzinoridze et al. (1978), which developed from studies of Deep Sea Drilling Project (DSDP) Leg 38 sites in the eastern Norwegian-Greenland Sea. The composite zonation of Fenner (1985) is shown in Figure 2, along with the two new zones proposed in this study. As can be noted from Figure 2, available upper Paleogene biosiliceous sediments of the Norwegian-Greenland Sea provide only a fragmentary record, with poor chronostratigraphic control. Leg 151 contributed significantly to this record, but a complete composite section is still not available.

Lower latitude zonations, including those used by Baldauf and Monjanel (1989) from the Labrador Sea, proved of rather limited value, due to the fact that few of the low-latitude biostratigraphic markers used in that study are present in sufficient abundance in Leg 151 material for reliable application. Many Oligocene taxa present in the Norwegian-Greenland Sea also occur in the southern high latitudes, where chronostratigraphic control is, on the whole, rather good. This allows a bipolar comparison of taxonomic distributions, but the poor chronostratigraphic control presently available in the NorwegianGreenland Sea prevents reliable evaluation of bipolar diachrony or isochrony of diatom events.

Three new Paleogene diatom biozones are defined, based on analysis of ODP Leg 151 sediments. An additional contribution to the diatom biostratigraphic zonation for the Norwegian-Greenland Sea is the recognition and definition of an older base for the Sceptroneis

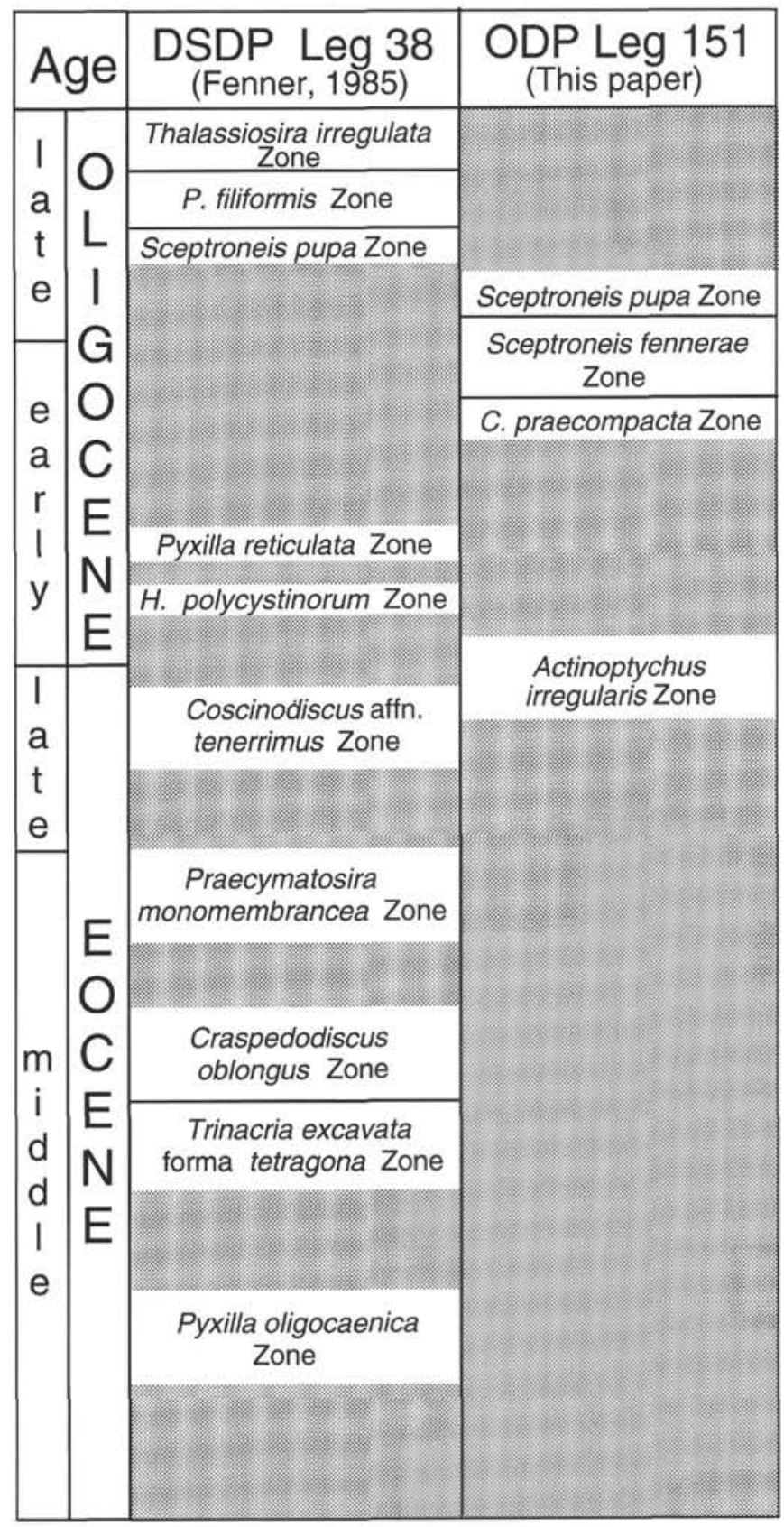

Figure 2. Diatom biozones, and their approximate ages, for the NorwegianGreenland Sea, based on analysis of DSDP Leg 38 (Fenner, 1985; Dzinoridze et al., 1978; Schrader and Fenner, 1976) and ODP Leg 151 (this study), including new biozones defined here. Shaded areas are unzoned due to a lack of recovery or a lack of diatom occurrences in recovered sediments.

pupa Zone than was originally defined by Schrader and Fenner (1976) and Fenner (1985).

\section{Definition of Paleogene Diatom Biozones of Leg 151}

Total range zone: Sceptroneis pupa Zone (Schrader and Fenner, 1976; Fenner, 1985; Scherer and Koç, this study)

Age: early late Oligocene. 
Definition: The top of the upper Oligocene $S$. pupa Zone, as defined by Schrader and Fenner (1976) and Fenner (1985), is the last occurrence of $S$. pupa, coinciding with the first occurrence of Lisitzinia ornata. Other floral elements include Cavitatus jouseanus and Sceptroneis pesplanus. The base of this zone, as originally defined from DSDP Site 338, coincides with a hiatus. The base of the $S$. pupa Zone is now extended, based on materials recovered from Hole 908A. The base is now defined as the first occurrence of $S$. pu$\mathrm{pa}$, which coincides with the last occurrence of Sceptroneis fennerae $\mathrm{n}$. sp. The first occurrence of Rhizosolenia oligocaenica var. stylifor$m a \mathrm{n}$. var. and the last occurrences of Melosira ignota and "Detonia?" sp. A are also associated with this zonal boundary in Hole 908A. Sceptroneis pesplanus is not found in the lower part of the $S$. pupa Zone of Hole 908A.

Total range zone: Sceptroneis fennerae Zone (Scherer and Koç, this study)

Age: late early to early late Oligocene

Definition: The top of this zone is defined by the last occurrence of Sceptroneis fennerae and the first consistent occurrence of $S$. pupa. Also associated with this boundary are the last consistent occurrences of "Detonia?" sp. A and Melosira ignota, and the first occurrence of Rhizosolenia oligocaenica var. styliforma. Other distinctive floral elements of the $S$. fennerae Zone include Goniothecium decoratum, Cavitatus jouseanus, Eurossia irregularis, Thalassiosira nansenii $\mathrm{n}$. sp., Pseudotriceratium radiosoreticulatum and Rhizosolenia oligocaenica. Goniothecium coronata occurs only in the upper part of the S. fennerae Zone, and Hemiaulus incisus occurs in the lower part. The base of the zone is defined by the first occurrences of Sceptroneis fennerae and Sceptroneis humuncia var. rondipoda n. var.

Assemblage zone: Cymatosira praecompacta (Scherer and Koç, this study)

Age: early Oligocene

Definition: Characterized by common and morphologically diverse examples of $C$. praecompacta. The top of the zone is defined by the first occurrence of Sceptroneis fennerae and $S$. humuncia var. rondipoda. Other floral elements include Macrora barbadensis, Hemiaulus hostilis, Melosira ignota, "Detonia?" spp., and Thalassiosira nansenii with a raised center, which is interpreted as a transitional form between Thalassiosira mediaconvexa and $T$. nansenii. The assemblage also includes Rhizosolenia oligocaenica, Pseudotriceratium radiosoreticulatum, Trochosira spinosa, and rare Craspedodiscus spp. and Distephanosira architecturalis. The bottom of the zone is not defined.

Assemblage zone: Actinoptychus irregularis Zone (Scherer and Koç, this study)

Age: late late Eocene/early early Oligocene

Definition: This is an assemblage zone for which the upper and lower boundaries cannot be formally defined based on available materials, because the upper and lower contacts coincide with lithologic changes. Distinctive floral elements of this assemblage include Actinoptychus irregularis, Coscinodiscus affn. tenerrimus, Navicula udintsevii, Costopyxis trochlea, Thalassiosira mediaconvexa, Thalassiosira dubiosa, and Sceptroneis mayenica. Floral elements resemble the Coscinodiscus affn. tenerrimus Zone of Dzinoridze et al. (1978) and Fenner (1985), but the stratigraphic sections are not long enough or complete enough to determine the relative chronostratigraphic positions of these assemblages with assurance.

\section{DIATOM ASSEMBLAGES BY SITE}

\section{Site 908}

Two holes were drilled at Site 908 on the Hovgaard Ridge in the Fram Strait. The Hovgaard Ridge is a displaced block that likely rifted from the Svalbard margin. This ridge has considerable oceanographic and paleoceanographic significance in that it comprises a sig- nificant part of the complex sill separating the Arctic Ocean and the Norwegian-Greenland Sea. Only Hole 908A, which penetrated below the unconformity recognized by seismic stratigraphy, recovered Paleogene sediment. A total of $180 \mathrm{~m}$ of Paleogene diatomaceous sediments was recovered. These successions lie between lower Pliocene to recent largely unfossiliferous sediments above the unconformity, which is identified at $185 \mathrm{~m}$ below seafloor (mbsf), and 24 $\mathrm{m}$ of largely unfossiliferous Paleogene sediments below the biosiliceous unit. Diatom abundance and preservation throughout this 180 $\mathrm{m}$ unit fluctuates from abundant and well preserved to nearly barren and very poorly preserved. The low abundance zones may represent brief hiatuses, but the diatoms do not indicate any significant stratigraphic gaps within these intervals. Qualitative diatom abundance through the interval is shown in Table 2 and graphically in Figure 3, plotted by depth.

The Paleogene diatom assemblage of Hole $908 \mathrm{~A}$ is characterized by abundant and diverse meroplanktonic (largely resting spore forming), epiphytic, and epibenthic diatoms, indicating a neritic and relatively low salinity setting. Holoplanktonic diatoms are present in Site 908 Paleogene sediments, but these are of lower abundance than neritic indicators. Resting spores of numerous genera, including Chaetoceros and other spore-forming "genera" (e.g., Pseudopyxilla, Goniothecium, Stephanogonia, Xanthiopyxis; see discussion on spore genera in Hargraves, 1986), dominate the assemblage. A near-shore setting is indicated by the occurrence of common epipsammic, epipelic, and epibenthic diatom taxa, as interpreted based on modern analogs for the genera (generally following Round et al., 1990). Epilithic/epipelic taxa include members of the genera Paralia, "Detonia?", Diploneis, Cocconeis, Grammatophora, Rhaphoneis, Mastagloia, Eunotigramma, Aulacodiscus, and others. Taxa considered to represent the coastal plankton include Cymatosira, Odontella, and Neodelphineis as well as meroplanktonic genera Chaetoceros, Stephanopyxis, etc. Marine epiphytic diatoms are also common in Hole 908A Oligocene sediments. These are best typified by the abundant and diverse Sceptroneis species. The abundance of diatoms whose modern analogs occupy a marine epiphytic habitat may suggest that planktonic marine macrophytes were abundant in the highlatitude Norwegian-Greenland Sea during time of deposition of these sediments.

The assemblage of Paleogene diatoms in Hole 908A is suggestive of rapid sediment accumulation in a continental shelf setting, though actual paleodepth cannot be determined accurately because shallowwater diatoms may be displaced down the slope. Benthic foraminiferal assemblages in these sediments suggest a deep shelf setting (Osterman, this volume). Nonmarine diatoms are consistently present, although generally in low abundance. The occurrence of these diatoms provides clear evidence of a continental sediment source. The freshwater diatoms present most often represent acid water habitats, such as coastal bogs and marshlands, as indicated the presence of acidophilic diatoms of the genera Eunotia and Pinnularia. Alaucoseira spp. are also present. Melosira ignota is a consistent contributor to the diatom assemblage, particularly in the Sceptroneis fennerae Zone and the upper part of the Cymatosira praecompacta Zone. $M$. ignota is an arctic species, having been described from Oligocene sediments from western Siberia (Rubina, 1962; Gleser et al., 1992). The type section for M. ignota is described as nonmarine (Rubina, 1962), but the common occurrences of this taxon in Site 908 sediments argue against a strictly nonmarine, habitat. "Fragilaria" miocenica co-occurs with $M$. ignota in western Siberian strata (Rubina, 1968) as well as in Hole 908A. The diatom assemblage of Hole 908A suggests low salinity, marginal marine conditions.

Abundant Chaetoceros and morphologically similar diatom resting spores is generally interpreted as indicating high productivity and high sediment accumulation rates, typically a coastal upwelling setting. Another common habitat for high Chaetoceros productivity is a strongly stratified, stable water column with low salinity surface wa- 
Table 2. Paleogene diatom samples, depth, and abundance, Hole 908A.

\begin{tabular}{|c|c|c|c|c|c|}
\hline $\begin{array}{l}\text { Core, section, } \\
\text { interval }(\mathrm{cm})\end{array}$ & $\begin{array}{l}\text { Depth } \\
\text { (mbsf) }\end{array}$ & $\begin{array}{l}\text { Abundance } \\
\text { code }\end{array}$ & $\begin{array}{l}\text { Core, section, } \\
\text { interval }(\mathrm{cm})\end{array}$ & $\begin{array}{l}\text { Depth } \\
\text { (mbsf) }\end{array}$ & $\begin{array}{l}\text { Abundance } \\
\text { code }\end{array}$ \\
\hline \multicolumn{3}{|l|}{ 151-908A- } & $30 X-1,90-91$ & 274.8 & 9 \\
\hline $20 X-4,101-102$ & 183.0 & 1 & $30 X-2,6-7$ & 275.5 & 9 \\
\hline $20 X-5,14-15$ & 183.6 & 1 & $30 \times-2,96-97$ & 276.4 & 9 \\
\hline $20 X-5,48-49$ & 183.9 & 5 & $30 X-3,3-4$ & 276.9 & 1 \\
\hline $20 X-5,80-82$ & 184.2 & 3 & $30 \times-3,105-106$ & 277.0 & 1 \\
\hline $20 \mathrm{X}-5,146-148$ & 184.9 & 1 & $30 \times-4,3-4$ & 278.4 & 9 \\
\hline $20 X-6,48-49$ & 185.4 & 1 & $30 X-4,92-93$ & 279.3 & 9 \\
\hline $20 X-6,114-116$ & 186.0 & 1 & $30 X-2,6-7$ & 275.5 & 9 \\
\hline $20 X-6,144-145$ & 186.3 & 1 & $30 X-5,90-91$ & 280.8 & 5 \\
\hline $20 \mathrm{X}-\mathrm{CC}$ & 187.1 & 6 & $30 \times-6,68-69$ & 282.1 & 5 \\
\hline $21 X-1,77-78$ & 187.9 & 7 & $30 \times-7,4-5$ & 282.9 & 3 \\
\hline $21 X-2,146-147$ & 190.1 & 9 & $30 \mathrm{X}-\mathrm{CC}$ & 283.5 & 1 \\
\hline $21 X-3,30-31$ & 191.2 & 9 & $31 X-1,8-9$ & 283.6 & 9 \\
\hline $21 X-4,15-16$ & 192.6 & 7 & $31 X-1,78-79$ & 284.3 & 1 \\
\hline $21 X-4,144-145$ & 193.0 & 7 & $31 X-2,5-6$ & 285.1 & 4 \\
\hline $21 X-5,75-76$ & 193.9 & 9 & $31 X-3,4-5$ & 286.5 & 3 \\
\hline $21 X-6,40-41$ & 195.0 & 9 & $31 X-4,3-4$ & 288.0 & 1 \\
\hline $21 X-6,144-145$ & 196.0 & 7 & $31 X-4,71-73$ & 288.7 & 1 \\
\hline $21 \mathrm{X}-\mathrm{CC}$ & 196.7 & 7 & $31 X-5,2-3$ & 289.5 & 1 \\
\hline $22 X-1,68-69$ & 197.4 & 5 & $31 X-6,4-5$ & 291.0 & 4 \\
\hline $22 \mathrm{X}-1,129-131$ & 198.0 & 5 & $31 X-6,25-27$ & 291.2 & 5 \\
\hline $22 \mathrm{X}-2,129-131$ & 199.5 & 4 & $31 X-7,3-4$ & 292.5 & 8 \\
\hline $22 \mathrm{X}-3,72-73$ & 200.4 & 5 & $31 X-7,26-29$ & 292.8 & 8 \\
\hline $22 \mathrm{X}-3,130-132$ & 201.0 & 5 & $31 \mathrm{X}-\mathrm{CC}$ & 293.2 & 9 \\
\hline $22 X-4,129-131$ & 202.5 & 6 & $32 \mathrm{X}-1,9-10$ & 294.1 & 8 \\
\hline $22 \mathrm{X}-5,139-140$ & 204.1 & 5 & $32 X-1,97-98$ & 295.0 & 9 \\
\hline $22 X-6,6-8$ & 204.3 & 3 & $32 X-2,3-4$ & 294.7 & 9 \\
\hline $22 \mathrm{X}-\mathrm{CC}$ & 206.3 & 5 & $32 X-2,96-97$ & 295.7 & 9 \\
\hline $23 \mathrm{X}-1,3-4$ & 206.4 & 5 & $32 X-3,4-5$ & 296.2 & 9 \\
\hline $23 \mathrm{X}-1,81-82$ & 207.1 & 6 & $32 X-3,88-89$ & 297.1 & 9 \\
\hline $23 X-2,3-4$ & 207.8 & 5 & $32 X-4,5-6$ & 297.8 & 9 \\
\hline $23 \mathrm{X}-2,81-82$ & 208.6 & 9 & $32 X-4,88-89$ & 298.6 & 9 \\
\hline $23 \mathrm{X}-3,4-5$ & 209.3 & 9 & $32 X-5,4-5$ & 299.2 & 8 \\
\hline $23 X-4,3-3$ & 210.6 & 9 & $32 X-5,94-95$ & 300.1 & 9 \\
\hline $23 X-4,81-82$ & 211.4 & 9 & $32 \times-6,4-5$ & 300.7 & 8 \\
\hline $23 X-5,2-3$ & 212.3 & 9 & $32 X-6,90-91$ & 301.6 & 5 \\
\hline $23 X-5,81-82$ & 213.1 & 7 & $32 X-7,2-3$ & 302.2 & 8 \\
\hline $23 X-6,4-5$ & 213.8 & 7 & $32 X-7,46-47$ & 302.7 & 9 \\
\hline $23 X-7,3-4$ & 215.3 & 9 & $32 \mathrm{X}-\mathrm{CC}$ & 302.8 & 9 \\
\hline $23 \mathrm{X}-\mathrm{CC}$ & 216.0 & 9 & $33 X-1,17-18$ & 303.0 & 8 \\
\hline $24 X-1,83-84$ & 216.8 & 5 & $33 X-1,101-103$ & 303.8 & 8 \\
\hline $24 X-2,95-96$ & 218.4 & 5 & $33 X-2,3-4$ & 304.3 & 8 \\
\hline $24 X-3,131-132$ & 220.3 & 9 & $33 X-2,95-97$ & 305.3 & 9 \\
\hline $24 X-4,47-48$ & 221.0 & 9 & $33 X-3,4-5$ & 305.8 & 8 \\
\hline $24 X-4,90-91$ & 221.4 & 9 & $33 \mathrm{X}-3,91-93$ & 306.7 & 9 \\
\hline $24 X-5,77-79$ & 222.8 & 9 & $33 X-4,3-4$ & 307.3 & 8 \\
\hline $24 X-6,86-87$ & 224.4 & 9 & $33 \times-4,93-95$ & 308.2 & 9 \\
\hline $24 X-7,34-35$ & 225.3 & 9 & $33 X-5,15-16$ & 309.7 & 8 \\
\hline $24 \mathrm{X}-\mathrm{CC}$ & 225.6 & 9 & $33 X-5,88-90$ & 309.7 & 8 \\
\hline $25 \mathrm{X}-1,86-87$ & 226.5 & 9 & $33 X-6,5-6$ & 310.4 & 8 \\
\hline $25 X-2,108-109$ & 228.2 & 7 & $33 X-6,90-92$ & 311.2 & 9 \\
\hline $25 X-3,90-91$ & 229.5 & 7 & $33 X-7,4-5$ & 311.8 & 8 \\
\hline $25 X-4,90-91$ & 231.0 & 8 & $33 X-7,46-48$ & 312.3 & 9 \\
\hline $25 X-5,90-91$ & 232.5 & 9 & $33 \mathrm{X}-\mathrm{CC}$ & 312.5 & 9 \\
\hline $25 \mathrm{X}-\mathrm{CC}$ & 235.2 & 9 & $34 X-1,30-31$ & 312.8 & 3 \\
\hline $26 \mathrm{X}-1,80-81$ & 236.0 & 5 & $34 X-1,86-87$ & 313.4 & 3 \\
\hline $26 X-2,73-74$ & 237.4 & 8 & $34 X-2,8-9$ & 314.1 & 7 \\
\hline $26 \mathrm{X}-3,90-91$ & 239.1 & 9 & $34 X-3,5-6$ & 315.6 & 8 \\
\hline $26 \mathrm{X}-4,74-75$ & 240.4 & 4 & $34 X-3,85-86$ & 316.4 & 9 \\
\hline $26 \mathrm{X}-5,57-59$ & 241.8 & 3 & $34 X-4,5-6$ & 317.1 & 7 \\
\hline $26 X-5,70-71$ & 241.9 & 3 & $34 X-4,85-86$ & 317.9 & 9 \\
\hline $26 \mathrm{X}-6,93-94$ & 243.5 & 3 & $34 X-5,5-6$ & 318.6 & 4 \\
\hline $26 \mathrm{X}-\mathrm{CC}$ & 244.9 & 4 & $34 X-5,92-93$ & 319.4 & 3 \\
\hline $27 X-1,76-78$ & 245.7 & 5 & $34 \mathrm{X}-\mathrm{CC}$ & 320.2 & 3 \\
\hline $27 X-2,79-81$ & 247.2 & 5 & $35 X-1,21-22$ & 320.4 & 2 \\
\hline $27 X-3,119-121$ & 249.1 & 6 & $35 X-1,85-86$ & 321.1 & 3 \\
\hline $27 X-4,81-83$ & 250.2 & 7 & $35 X-2,8-9$ & 321.8 & 4 \\
\hline $27 X-5,44-46$ & 251.3 & 8 & $35 X-2,131-132$ & 323.0 & 3 \\
\hline $27 \mathrm{X}-\mathrm{CC}$ & 254.6 & 3 & $35 X-3,5-6$ & 323.3 & 3 \\
\hline $28 X-1,77-79$ & 255.4 & 4 & $35 X-3,115-117$ & 324.4 & 4 \\
\hline $28 X-2,3-4$ & 256.1 & 3 & $35 X-4,7-8$ & 324.8 & 4 \\
\hline $28 X-2,105-108$ & 257.2 & 3 & $35 X-4,84-85$ & 325.5 & 3 \\
\hline $28 X-3,77-79$ & 258.4 & 3 & $35 X-5,9-10$ & 326.3 & 2 \\
\hline $28 \mathrm{X}-3,139-140$ & 259.0 & 4 & $35 X-5,105-106$ & 327.3 & 1 \\
\hline $28 X-4,68-70$ & 259.8 & 3 & $35 X-6,22-23$ & 328.0 & 2 \\
\hline $28 X-5,87-89$ & 261.5 & 7 & $35 \mathrm{X}-\mathrm{CC}$ & 330.1 & 2 \\
\hline $28 X-6,70-72$ & 262.8 & 7 & $36 X-1,91-92$ & 331.0 & 1 \\
\hline 28X-CC & 264.2 & 6 & $36 X-2,63-64$ & 332.3 & 1 \\
\hline $29 X-1,114-115$ & 265.3 & 4 & $36 X-3,105-106$ & 334.2 & 1 \\
\hline $29 X-2,114-115$ & 266.8 & 3 & $36 \times-4,83-86$ & 335.4 & 1 \\
\hline $29 X-3,114-115$ & 268.3 & 2 & $36 \mathrm{X}-\mathrm{CC}$ & 340.0 & 1 \\
\hline $29 X-4,5-6$ & 268.8 & 3 & $37 X-1,66-67$ & 340.7 & 1 \\
\hline $29 X-4,114-115$ & 269.8 & 5 & $37 X-2,50-51$ & 342.7 & 1 \\
\hline $29 X-5,122-123$ & 271.4 & 8 & $37 X-2,80-81$ & 343.1 & 1 \\
\hline $29 \mathrm{X}-6,122-123$ & 272.9 & 8 & $37 \mathrm{X}-\mathrm{CC}$ & 344.6 & 1 \\
\hline 29X-CC & 273.9 & 9 & & & \\
\hline $30 X-1,13-14$ & 274.0 & 9 & (l) & & ed. \\
\hline
\end{tabular}

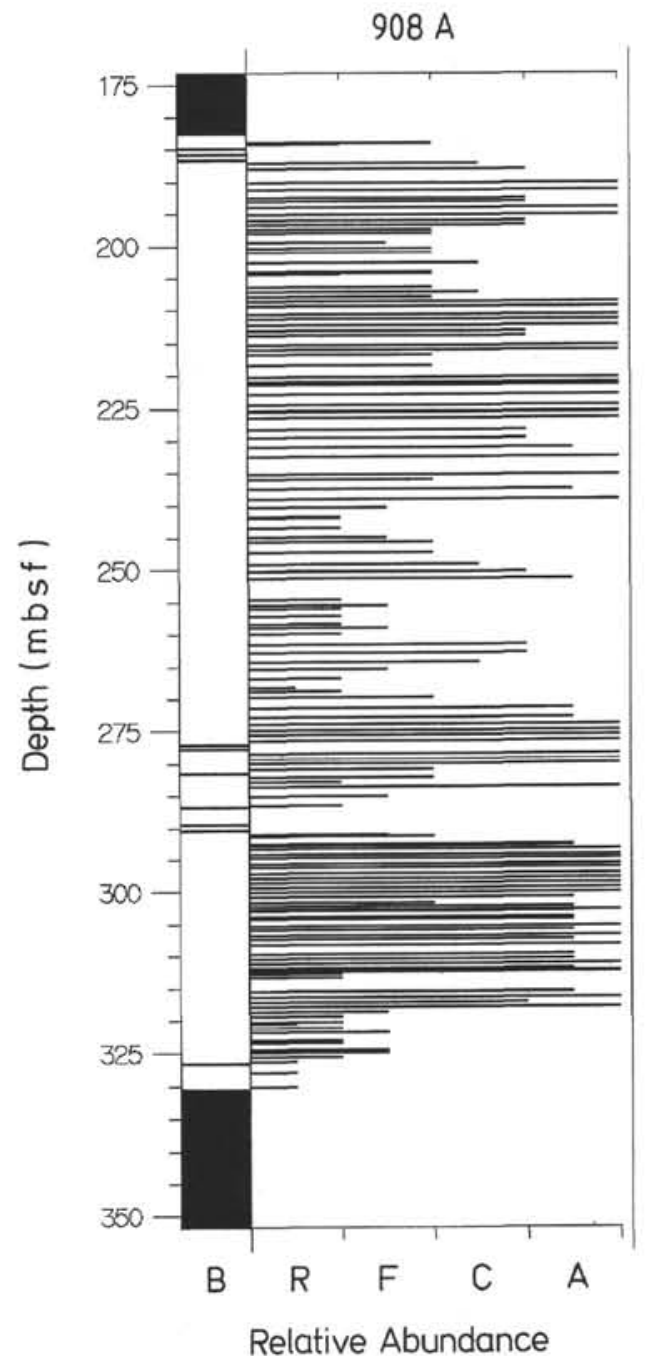

Figure 3. Diatom relative abundance in Paleogene sediments of Hole 908A, plotted on a linear depth scale. Abundance is based on smear-slide analysis. See Table 1 for definition of the abundance categories. Barren samples or intervals are indicated in black in the left column. Data are from Table 2.

ters (Leventer, 1991). Relatively low salinity conditions are also suggested by diatoms Melosira ignota, Mastagloia and others. It is interesting to note that the high surface-water productivity that characterized the early to middle Oligocene Fram Strait region, as evidenced by the abundant meroplanktonic diatoms of Hole 908A, apparently shut down before early Miocene time. This is suggested by sediments recovered from the nearby Site 909 . Hole $909 \mathrm{C}$ recovered a thick Miocene section that lacks all evidence of biosiliceous productivity, despite high Miocene diatom productivity on the Vøring Plateau and the Iceland Plateau. Dissolved silica in the pore waters of the lower section of Hole 909C is so low that it seems unlikely that significant biosiliceous debris ever accumulated in this region at that time. Pore water silica concentrations in the lower part of Hole $909 \mathrm{C}$ are as low as $\sim 100 \mu \mathrm{mol} / \mathrm{L}$, compared with the Oligocene sequence of Hole $908 \mathrm{~A}$, which has pore water silica concentrations exceeding 1000 $\mu \mathrm{mol} / \mathrm{L}$ (Myhre, Thiede, Firth, et al., 1995). It is not yet clear how the relative paleogeographic positions of Site 908 and Site 909 influenced the dramatic differences in diatom paleoproductivity and accumulation, but the sediments do suggest significant ecological differences between Miocene Arctic and Norwegian-Greenland Sea waters. 
Table 3. Paleogene diatom occurrence and abundance in Hole 908A.

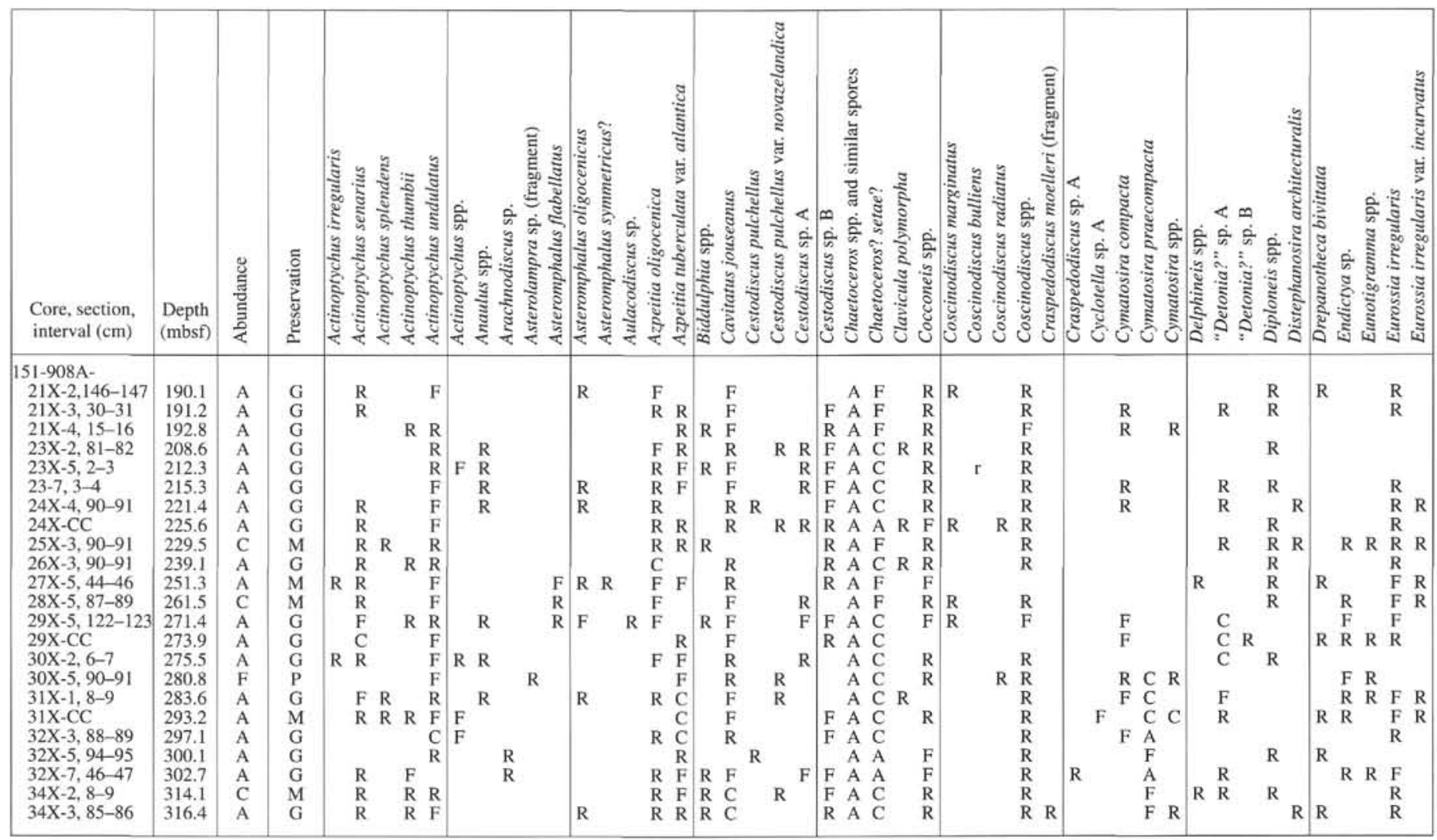

The Sceptroneis pupa Zone is recognized from Samples 151908A-21X-2, 146-147 cm (190.1 mbsf), down to $23 \mathrm{X}-2,81-82 \mathrm{~cm}$ (208.6 mbsf) (Fig. 4). Significant floral elements include Asteromphalus oligocenicus, Azpeitia oligocaenica, Azpeitia tuberculata var. atlantica, Cavitatus jouseanus, Cymatosira compacta, C. praecompacta, Eurossia irregularis, E. irregularis var. incurvatus, Goniothecium coronatum, $G$. decoratum, Pseudotriceratium radiosoreticulatum, Pyxilla oligocaenica, Rhizosolenia oligocaenica, Rhizosolenia oligocaenica var. styliforma, Rocella praenitida, Sceptroneis humuncia var. rondipoda, S. praecaducea, S. propinqua, S. pupa, S. tenue, $S$. vermiformis, Thalassiosira nansenii, and Trochosira spinosa, as well as rare Cestodiscus pulchellus var. novazealandica and Rutilaria areolata (Table 3 ).

The Sceptroneis fennerae Zone is recognized from Sample 151908A-23X-5, 2-3 cm (212.3 mbsf), to $32 X-7,46-47 \mathrm{~cm}$ (302.7 mbsf) (Fig. 4). This assemblage includes many of the above taxa, but lacks $S$. pupa and $R$. oligocaenica var. styliforma. Unique elements include Sceptroneis fennerae, Melosira ignota, and "Detonia?" sp. A. The lower part of the Sceptroneis fennerae Zone includes Cymatosira praecompacta, Thalassiosira nansenii/mediaconvexa transitional forms, and Macrora spp. Goniothecium coronata occurs only in the upper part of the zone, and Hemiaulus incisus occurs in the lower part.

The Cymatosira praecompacta Zone is recognized from Sample 151-908A-33X-2, 95-97 cm, to the base of the biosiliceous interval at Sample 151-908A-34X-5, 5-6 cm (Fig. 4). The diatom assemblage is similar to that of the $S$. fennerae Zone. Melosira ignota, "Detonia?" sp. A, and "Fragilaria" miocenica occur in the upper part of the zone. Craspedodiscus spp. and Distephanosira architecturalis occur in low abundance in the lower part of the zone. Widespread lower Oli- gocene markers, such as Cestodiscus reticulatus and Cestodiscus antarcticus, are not found in Site 908 Paleogene sediments.

\section{Site 913}

Two holes were drilled at Site 913, along the East Greenland Margin. Hole 913B penetrated into Paleogene sediments. Continuous drilling began at $423.5 \mathrm{mbsf}$ (Core 151-913B-20R) and ended in a lithified sandstone at $721.9 \mathrm{mbsf}$ (Core 151-913B-51R). Diatoms and other siliceous microfossils are abundant in Cores 151-913B-24R through $27 \mathrm{R}$ and sporadic in other cores. The diatom-rich successions are characterized by complex lithologic and sedimentary structural changes. Diatom abundance throughout the biosiliceous interval is shown in Figure 5 and Table 4. Much of the diatom-rich interval is finely laminated, suggesting low oxygen bottom conditions. Interestingly, near the top of the biosiliceous interval (in Section 151-913B24R-4) dominance changes upward from diatoms to radiolarians and radiolarian fragments, before biogenic siliceous particles virtually disappear in Section 151-913B-24R-2. The sediments at the top of the biosiliceous interval have a coarser texture, containing less clay and more silt-sized material than above or below, which may suggest winnowing by bottom currents. Samples 151-913B-24R-2, 38-39 $\mathrm{cm}$, through $24 \mathrm{R}-4,43-45 \mathrm{~cm}$, contain relatively rare diatoms (Fig. 3 ), and there is a concurrent increase in the abundance of radiolarians and other larger grains. This interval contains the textural characteristics of a typical contourite (Cremer et al., this volume). In situ Paleogene diatoms are absent above Sample 151-913B-24R-2, $38 \mathrm{~cm}$.

Samples between 151-913B-24R-4, 54-56 cm, and 27R-3, 137$138 \mathrm{~cm}$, contain common to abundant, diverse (more than 100 taxa) and often well-preserved diatoms in sediments that are commonly 
Table 3 (continued).

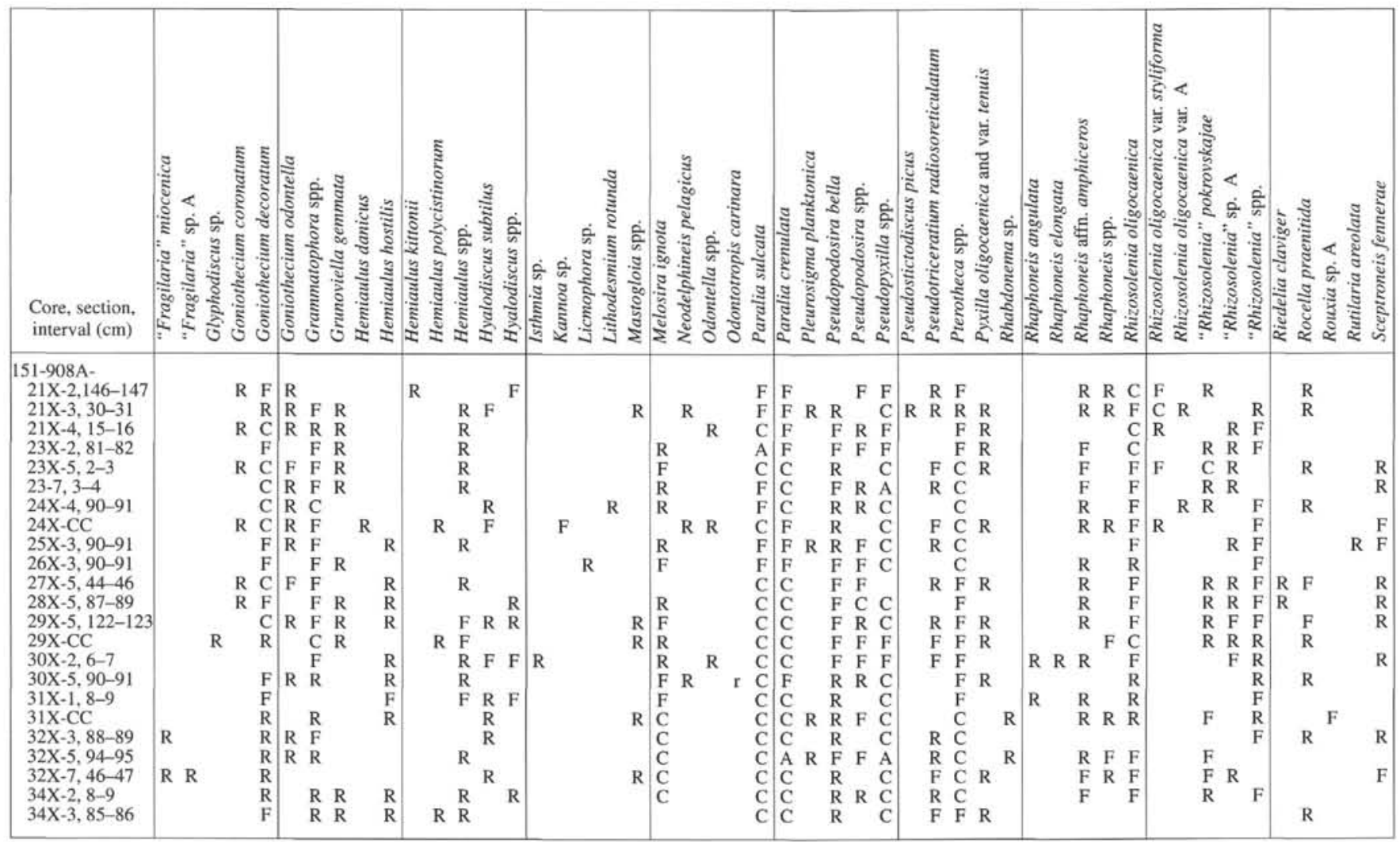

laminated. Unlike the Paleogene diatom assemblage of Site 908, the Paleogene diatoms of Site 913 include relatively abundant holoplanktonic taxa, including members of the genera Asterolampra, Cestodiscus, Coscinodiscus, and Thalassiosira. Many of these taxa are common in sediments deposited under open marine and relatively warm water conditions. This assemblage is characterized by Actinoptychus irregularis (a triangular form of $T$. undulatus), Asterolampra insignis, Asterolampra affinis, Asterolampra marylandica, Cestodiscus sp. 1 (= Cestodiscus sp. 9 of Baldauf and Monjanel, 1989), Coscinodiscus oligocenicus, Coscinodiscus affn. tenerrimus, Costopyxis trochlea, Cymatosira sp. A, Distephanosira architecturalis, Hemiaulus spp., Monobrachia spp., Navicula udintsevii, Paralia sulcata, Paralia crenulata, Pseudotriceratium cheneveri, Pterotheca aculeifera, Sceptroneis mayenica, Stephanopyxis turris, Thalassiosira dubiosa, Thalassiosira mediaconvexa, Trinacria excavata, Trochosira coronata, Tubaformis $\mathrm{cf}$. unicornis and Xanthiopyxis panduraeformis (Table 5). Resting spores of the genera Chaetoceros, Odontotropis, Pteriptera, Pseudopyxilla, Porotheca, Pterotheca, Xanthiopyxis, and others are common. The assemblage has both Eocene and Oligocene affinities, suggesting that the sediments were deposited very near to the Eocene/Oligocene boundary.

Diatoms that may suggest an early Oligocene age include $A$. irregularis, Cestodiscus sp. 1, N. udintsevii, certain Asterolampra spp., and $P$. cheneveri. However, most of the assemblage appears to imply a late Eocene age, based on the occurrence of diverse Asterolampra spp., $C$. oligocenicus, $C$. affn. tenerrimus, $C$. trochlea, $D$. architecturalis, Hemiaulus elegans, $H$. incisa, $H$. polycistinorum, and other Hemiaulus species, Monobrachia spp., P. aculeifera, S. mayenica, T. dubiosa, T. mediaconvexa, $T$. coronata, $T$. cf. unicornis, $X$. panduraeformis, and the absence of early early Oligocene diatoms such as Cestodiscus reticulatus. T. mediaconvexa occurs only in the lower part of this interval (Samples 151-913B-27R-5, 76-77 cm, through 26R-7, 17-19 cm), whereas $C$. affn. tenerrimus and Asterolampra spp. occur only in the upper part (Samples 151-913B-25R-5, 49-50 $\mathrm{cm}$, and 26R-3, 4-5 cm, respectively, through $24 \mathrm{R}-\mathrm{CC}$ ). It is unclear whether these appearances and disappearances are biostratigraphic, environmental and/or preservational. Another interesting observation is with regard to the occurrence of silicoflagellates. Sample 151913B-27R-2, 82-83 cm, contains very abundant and largely fragmented silicoflagellates, most of which are much larger than their typical size. The significance of this silicoflagellate "event" is unclear at present (see Locker, this volume).

The interval spanning Samples 151-913B-27R-5, 147-148 cm, to $24 \mathrm{R}-3,65-66 \mathrm{~cm}$, is assigned, in its entirety, to the Actinoptychus irregularis Zone (Fig. 4). The A. irregularis Zone assemblage of Site 913 most closely resembles that of DSDP Site 339, Cores 151-913B10R through 12R. The diatoms that Sites 913 and 339 have in common, based on comparison of Site 913 diatom data (this study) and results reported by Schrader and Fenner (1976) and Dzinoridze et al. (1978), include common A. irregularis plus A. undulatus, Asterolampra spp., Cestodiscus sp. A, C. oligocenicus, $C$. affn. tenerrimus, $C$. trochlea, Cymatosira sp. A, D. architecturalis, $H$. polycystinorum, $H$. polymorphous, M. unicornitus, N. udintsevii, P. cheneveri, Sceptroneis grunowii, "Synedra?" sp. $1, T$. excavata, $T$. coronata, and X. panduraeformis. Dzinoridze et al. (1978) assigned this interval (based on two samples) to a zone they defined as the "Unit with Coscinodiscus affn. tenerrimus." Site 339, Cores 339-6R through 339-8R contain common middle Eocene diatoms, as reported by Dzinoridze et al. (1978) and Schrader and Fenner (1976), but these are likely reworked. The diatom assemblage of Site 339 has been assigned a late Eocene age (Fenner, 1985), although there are no independent tests of that interpretation. The exact relative chronostratigraphic position of the A. irregularis Zone is unclear, but it may be, at least in part, equivalent to the Coscinodiscus affn. tenerrimus Zone of Dzinoridze et al. (1978) and Fenner (1985). Samples from Sections 151-913B$32 \mathrm{R}-7$ through $27 \mathrm{R}-4$ are largely barren of diatoms, with the excep- 
Table 3 (continued).

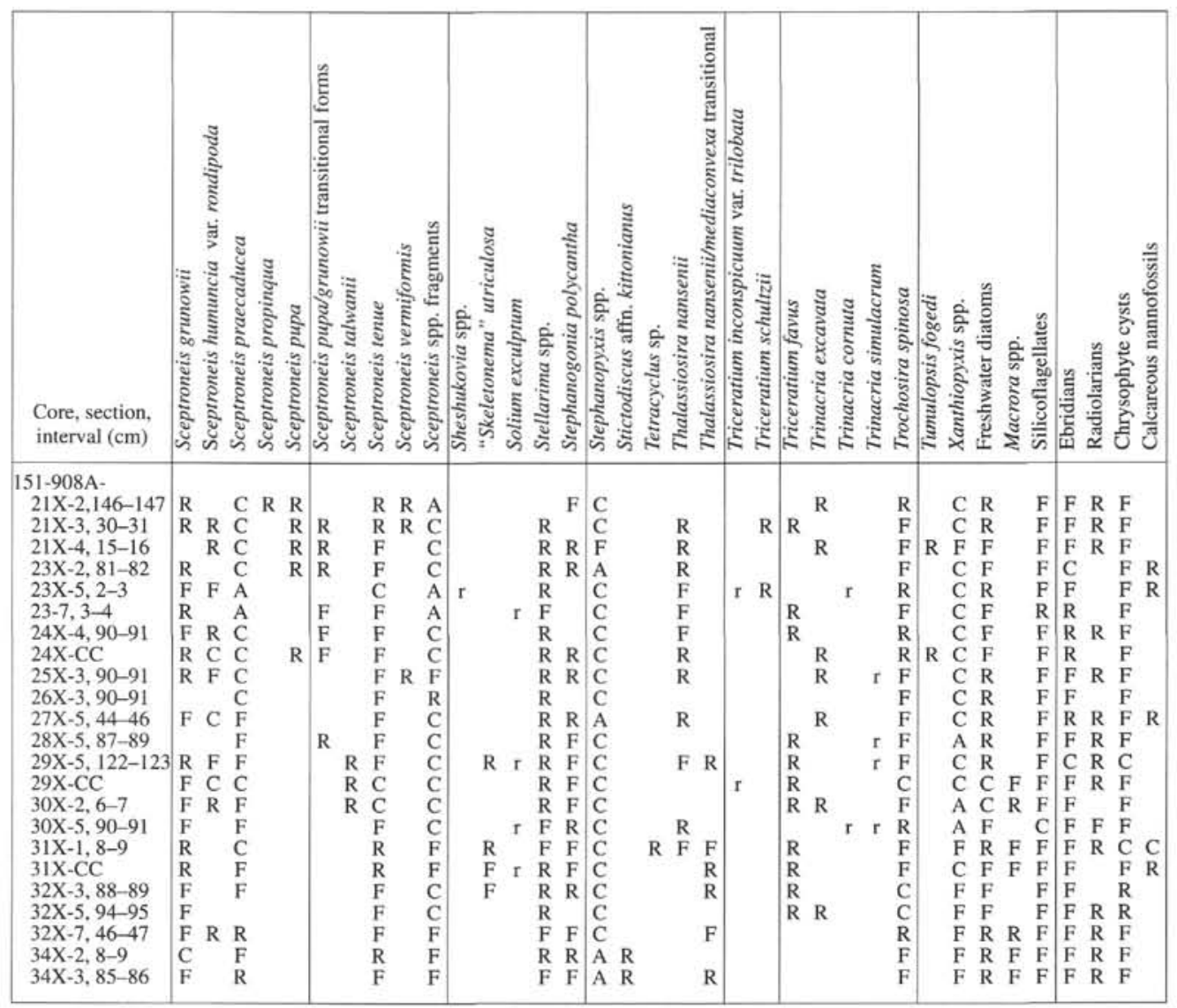

Note: Codes defined in Table 1.

tion of rare layers containing abundant but diagenetically altered diatom debris. Light gray layers rarely contain identifiable diatom debris, but some of the greenish layers do contain diatoms. However, few if any of these can be identified, due to diagenetic alteration. These layers are usually laminated and may represent productivity events over an oxygen-poor bottom.

The Paleogene diatom assemblage of the Actinoptychus irregularis Zone of Site 913 suggests a late late Eocene to early early Oligocene age, but the boundary cannot be defined based on diatoms at this time, due to the absence of well-dated regional reference sections and a lack of independent dating at this site. The Eocene/Oligocene boundary may lie within this interval. If, indeed, an Eocene/Oligocene boundary can be reliably identified in this interval (given, for example, improved magnetostratigraphy), then this may be an important site for Paleogene paleoceanography. The lithologic changes that occur through this interval, specifically the transition from low-oxygen bottom waters (laminated, organic-rich sediments) to invigorated bottom waters (winnowed sediments and contourite deposit) may record the pulse of Northern Component Water that flowed through the Norwegian-Greenland Sea, probably through a proto-Fram Strait, in the early early Oligocene, as described by Miller (1994). This was one of the defining events that led to the dramatic oceanographic and climatic changes of the Oligocene (Miller, 1994).

The oldest diatoms found in Hole 913B are replaced by pyrite. Most samples containing pyritized diatoms contain too few whole diatoms for even approximate biostratigraphic positioning. However, Sample 151-913B-32R-CC contains a sufficient abundance of pyritized diatoms for tentative biostratigraphic interpretation. The assemblage is dominated by Paralia sulcata, Anuloplicata ornata, and Stephanopyxis turris, with common occurrences of Coscinodiscus spp. and fragments of Craspedodiscus spp. A middle Eocene biostratigraphic age is suggested by the rare occurrence of Triceratium inconspicuum, plus Brightwellia sp., several species of small Triceratium, some of which may be $T$. inconspicuum var. trilobata, and rare specimens, mostly fragments, that are tentatively identified as Trinacria cornuta (formerly $T$. excavata forma tetragona). The assemblage described dates to the middle Eocene $T$. excavata forma tetragona Zone of Fenner (1985), but given the nature of preservation and the possibility that these pyritized diatoms may be reworked, this interpretation must be considered tentative.

\section{Other Occurrences of Paleogene Diatoms in Leg 151 Sediments}

Diatoms reworked from older deposits occur throughout the biosiliceous units of Sites 908 and 913 (Tables 2,4). Reworked taxa include Trinacria cornuta, Trinacria simulacrum, Triceratium inconspicuum var. trilobata, Sheshukovia spp., and Solium exculptum. Paleogene diatoms also occur in upper Neogene glacial units recovered from other Leg 151 sites, especially in the shallow water sites on the Yermak Plateau (Sites 910, 911, and 912). The reworked diatoms in these sequences were probably eroded and transported by either local or regional glacial activity. The glacial sedimentary units contain several "pulses" of reworked diatoms, including well-known lower Paleogene taxa such as certain Sheshukovia species, Anuloplicata ornata, Trinacria simulacrum, Solium exculptum, and Odontotropis spp. Many of these taxa occur in Paleocene and lower Eocene deposits in Denmark (Fur Formation, Fenner, 1994; Homann, 1991; Benda, 1972), on the Russian Plain and the flanks of the Urals (e.g., Gleser et al., 1992), and in the Arctic Ocean basin (Dell'Agnese and Clark, 


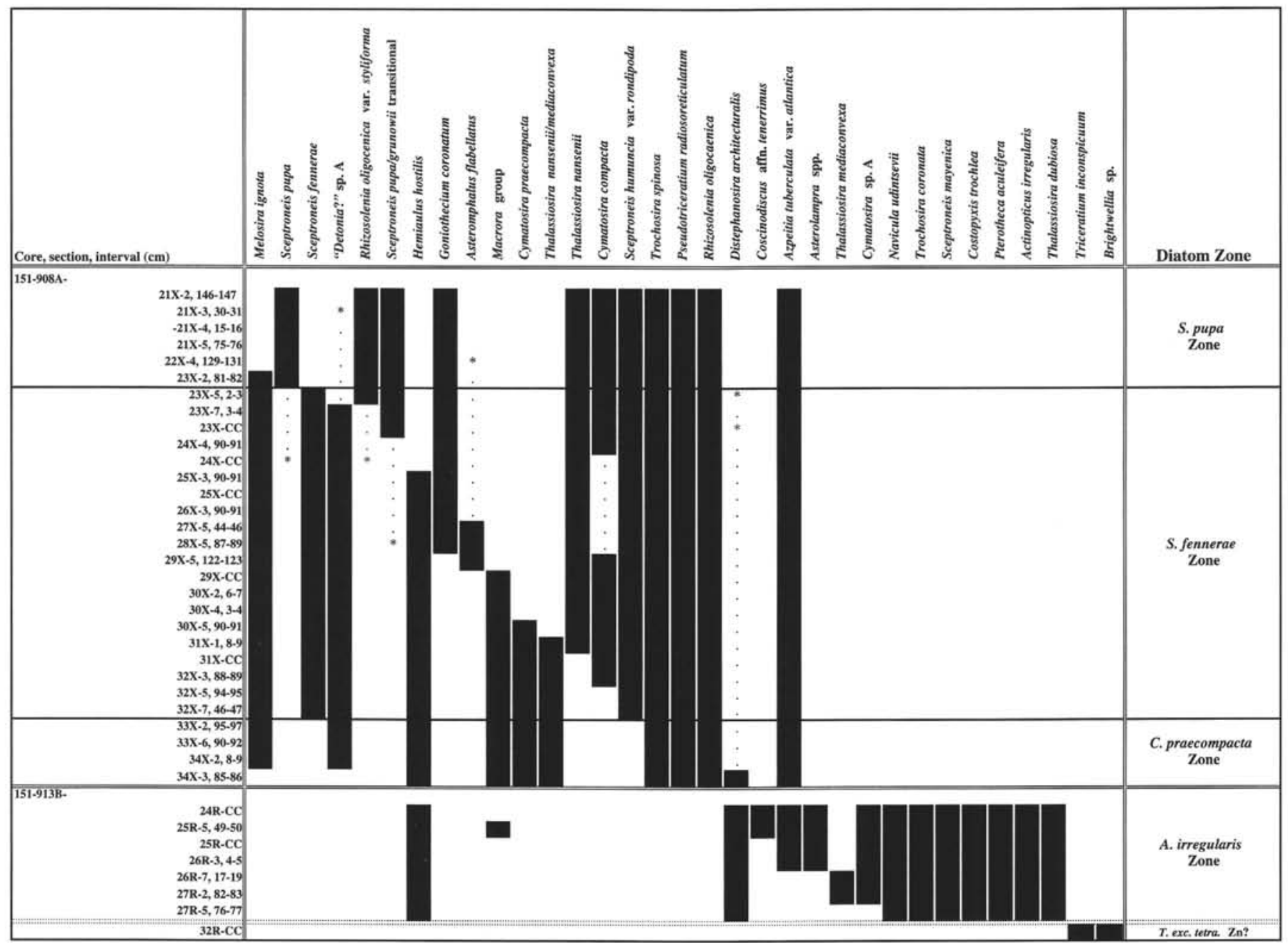

Figure 4. Range chart and zonal assignments for selected diatom taxa (plus Macrora spp.) in Sites 908 and 913 Paleogene sediments. Solid bars $=$ nearly continuous occurrences, ${ }^{*}=$ very rare or discontinuous occurrences.

1994). Some of these taxa were reported in dredge samples taken near Franz-Josef Land in 1872 (Grunow, 1884). These samples also represent reworked diatoms in glacial sediments.

\section{CONCLUSIONS}

ODP Leg 151 recovered biosiliceous Paleogene sediments that contribute to the development of a composite diatom stratigraphy for the Norwegian-Greenland Sea, although significant stratigraphic gaps remain. Sediments from Holes 908A and 913B are used to establish new diatom biozones, building on the framework established from DSDP Leg 38 from the works of Schrader and Fenner (1976), Dzinoridze et al. (1978), and Fenner (1985). Two new zones are established. The Sceptroneis fennerae Zone of the upper lower Oligocene lies conformably beneath the previously established lower upper Oligocene Sceptroneis pupa Zone. The lower Oligocene $C y$ matosira praecompacta Zone lies conformably beneath the $S$. fennerae Zone. The Actinoptychus irregularis Zone is established for an interval close to the Eocene/Oligocene boundary. This assemblage zone resembles the Coscinodiscus affn. tenerrimus Zone, but the exact stratigraphic relation between these assemblages is not known.

The accumulation of biosiliceous sediments in the NorwegianGreenland Sea during the Paleogene was influenced by both surface- water and bottom-water conditions. Diatom populations of the latest Eocene to earliest Oligocene included many species characteristic of low latitudes, indicating low provincialism and warm waters, although many low-latitude marker species are absent. By late early Oligocene time, diatom populations of the Norwegian-Greenland Sea developed considerable provincialism and latitudinal gradients. These population differences reflect changes in surface-water conditions. Changing bottom-water conditions along the East Greenland Margin during latest Eocene-earliest Oligocene time affected the accumulation and preservation of diatomaceous sediments in this region. Organic-rich laminated diatom oozes and muds, deposited under sluggish bottom flow and presumably low oxygen conditions, abruptly became winnowed by bottom current activity, perhaps in the early early Oligocene. Diatom-rich sediments winnowed to a radiolarian-rich deposit before all biosiliceous debris disappeared in a presumed hiatus. Primary productivity was generally high from the late early through the late Oligocene, although in the Fram Strait region diatom productivity was severely restricted during the Miocene. The diatom assemblages of the lower to middle Oligocene suggest rapid accumulation in a neritic environment under oxygenated bottom-water conditions. Late Pliocene and Pleistocene glaciations led to the erosion, transport and redeposition of lower Paleogene diatoms over a wide area from what were probably widespread deposits on the Barents Sea continental shelf and elsewhere. 
913 B

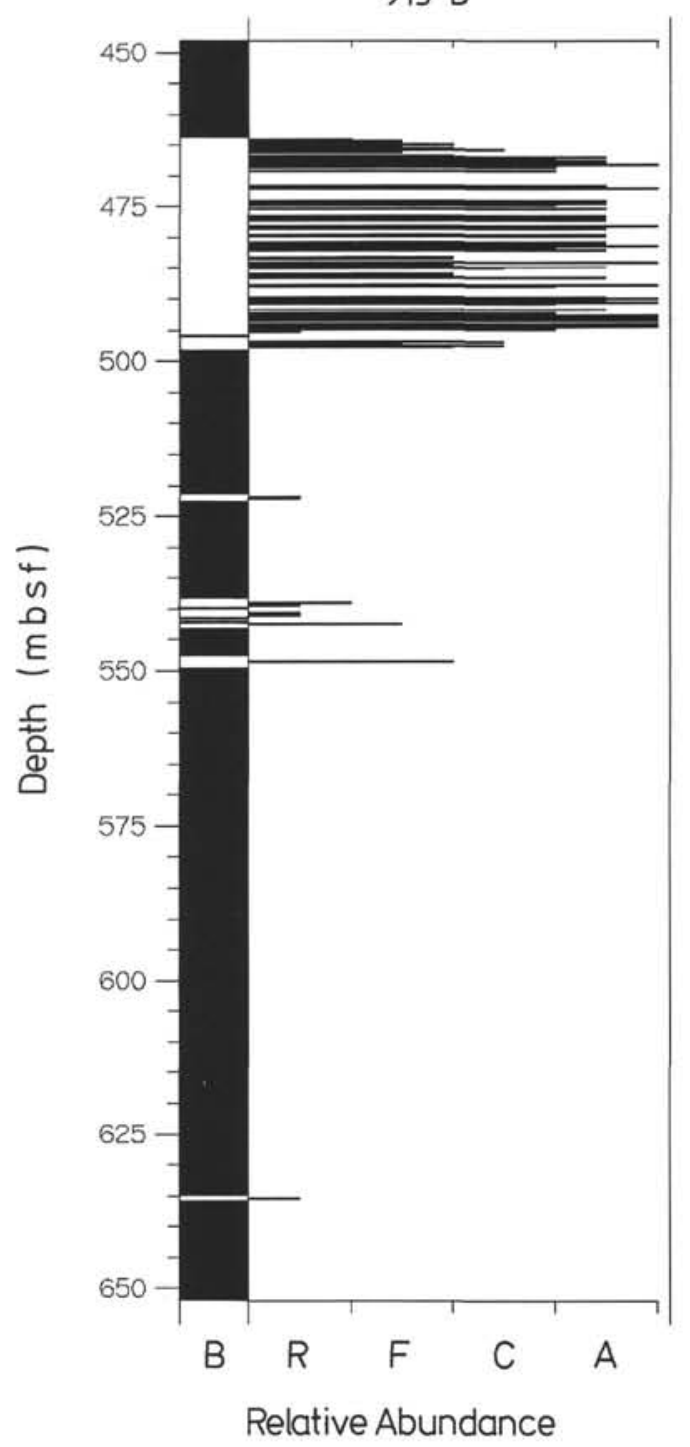

Figure 5. Diatom relative abundance in Paleogene sediments of Hole 913B, plotted on a linear depth scale. Abundance is based on smear-slide analysis. See Table 1 for definition of the abundance categories. Contourite deposit is recognized from 463.6 to $468.2 \mathrm{mbsf}$. Diatoms occurring below $539 \mathrm{mbsf}$ are preserved as pyrite replacements. Barren samples or intervals are indicated in black in the left column. Data are from Table 4. The vertical scale in meters is the same as that of Figure 3.

\section{TAXONOMIC NOTES}

Actinocyclus ehrenbergii group Ralfs in Prichard (1861); Schrader and Fenner (1976) pl. 14, fig. 17. (Pl. 5, Fig. 16)

Actinoptychus hexagonis var. tenella Schmidt in Schmidt et al. (1874) pl. 1, fig. 16

Actinoptychus delicatissimus Witt (1885) pl. 9, fig. 1. (Pl. 8, Fig. 12)

Actinoptychus irregularis Grunow in Van Heurck (1883) pl. 132, fig. 11. (Pl. 6, Figs. 10-13)

Synonyms: Actinoptychus sp. (triangular) Schrader and Fenner (1976) pl. 35 fig. 23 (late Eocene, Norwegian-Greenland Sea); Actinoptychus sp. (triangular) Yanagisawa and Suzuki (1987) pl. 1, figs. 3, 4 (early Oligocene, northern Japan).
Table 4. Paleogene diatom samples, depth, and abundance, Hole 913B.

\begin{tabular}{|c|c|c|}
\hline $\begin{array}{l}\text { Core, section, } \\
\text { interval }(\mathrm{cm})\end{array}$ & $\begin{array}{l}\text { Depth } \\
\text { (mbsf) }\end{array}$ & $\begin{array}{l}\text { Abundance } \\
\text { code }\end{array}$ \\
\hline \multicolumn{3}{|c|}{ 151-913B- } \\
\hline $23 \mathrm{R}-1,109-110$ & 452.5 & 1 \\
\hline $23 \mathrm{R}-1,127-128$ & 453.8 & i \\
\hline $24 \mathrm{R}-1,1-2$ & 462.0 & i \\
\hline $24 \mathrm{R}-1,11-12$ & 462.1 & i \\
\hline $24 \mathrm{R}-1,24-25$ & 462.2 & 1 \\
\hline $24 \mathrm{R}-1,28-30$ & 462.3 & 1 \\
\hline $24 \mathrm{R}-1,44-45$ & 462.4 & 1 \\
\hline $24 \mathrm{R}-1,48-49$ & 462.5 & 1 \\
\hline $24 \mathrm{R}-2,13-14$ & 463.6 & 2 \\
\hline $24 \mathrm{R}-2,38-39$ & 463.9 & 1 \\
\hline $24 \mathrm{R}-2,55-56$ & 464.1 & 2 \\
\hline $24 \mathrm{R}-2,56-58$ & 464.2 & 3 \\
\hline $24 \mathrm{R}-2,65-67$ & 464.2 & 3 \\
\hline $24 \mathrm{R}-2,102-103$ & 464.5 & 3 \\
\hline $24 \mathrm{R}-2,127-128$ & 464.8 & 4 \\
\hline $24 \mathrm{R}-2,137-138$ & 464.9 & 3 \\
\hline $24 \mathrm{R}-2,138-140$ & 465.1 & 3 \\
\hline $24 \mathrm{R}-3,16-17$ & 465.2 & 2 \\
\hline $24 \mathrm{R}-3,29-31$ & 465.3 & 3 \\
\hline $24 \mathrm{R}-3,40-41$ & 465.4 & 4 \\
\hline $24 \mathrm{R}-3,65-66$ & 465.7 & 5 \\
\hline $24 \mathrm{R}-3,100-101$ & 466.0 & 3 \\
\hline $24 \mathrm{R}-3,110-112$ & 466.1 & 3 \\
\hline $24 \mathrm{R}-4,23-24$ & 466.7 & 5 \\
\hline $24 \mathrm{R}-4,28-30$ & 466.8 & 5 \\
\hline $24 R-4,43-45$ & 466.9 & 8 \\
\hline $24 R-4,54-56$ & 467.0 & 7 \\
\hline $24 \mathrm{R}-4,87-88$ & 467.4 & 7 \\
\hline $24 \mathrm{R}-4,94-95$ & 467.5 & 8 \\
\hline $24 \mathrm{R}-4,126-127$ & 467.7 & 8 \\
\hline $24 \mathrm{R}-4,149-150$ & 468.0 & 7 \\
\hline $24 R-5,4-6$ & 468.0 & 7 \\
\hline $24 \mathrm{R}-5,9-11$ & 468.1 & 5 \\
\hline $24 \mathrm{R}-5,18-20$ & 468.2 & 9 \\
\hline $24 \mathrm{R}-5,36-37$ & 468.4 & 7 \\
\hline $24 \mathrm{R}-5,54-56$ & 468.5 & 7 \\
\hline $24 \mathrm{R}-5,107-108$ & 469.1 & 7 \\
\hline $24 \mathrm{R}-\mathrm{CC}$ & 471.6 & 8 \\
\hline $25 \mathrm{R}-1,16-17$ & 471.8 & 8 \\
\hline $25 \mathrm{R}-1,28-30$ & 471.9 & 9 \\
\hline $25 \mathrm{R}-1,43-44$ & 472.0 & 8 \\
\hline $25 \mathrm{R}-1,90-91$ & 474.1 & 8 \\
\hline $25 R-2,102-104$ & 474.2 & 8 \\
\hline $25 \mathrm{R}-2,121-123$ & 474.4 & 8 \\
\hline $25 \mathrm{R}-2,131-132$ & 474.5 & 7 \\
\hline $25 \mathrm{R}-3,13-15$ & 474.7 & 7 \\
\hline $25 \mathrm{R}-3,60-61$ & 475.2 & 8 \\
\hline $25 \mathrm{R}-3,98-100$ & 475.6 & 7 \\
\hline $25 \mathrm{R}-4,34-35$ & 476.4 & 8 \\
\hline $25 R-4,65-67$ & 476.7 & 8 \\
\hline $25 \mathrm{R}-4,91-92$ & 477.0 & 8 \\
\hline $25 \mathrm{R}-5,49-50$ & 478.0 & 9 \\
\hline $25 \mathrm{R}-5,62-63$ & 478.2 & 8 \\
\hline $25 \mathrm{R}-5,101-103$ & 478.5 & 8 \\
\hline $25 \mathrm{R}-6,49-50$ & 479.5 & 8 \\
\hline $25 \mathrm{R}-6,71-72$ & 479.8 & 8 \\
\hline $25 \mathrm{R}-6,157-158$ & 480.7 & 8 \\
\hline $25 \mathrm{R}-7,38-40$ & 481.0 & 8 \\
\hline $25 \mathrm{R}-7,52-53$ & 481.1 & 8 \\
\hline $25 \mathrm{R}-7,67-69$ & 481.2 & 8 \\
\hline $25 \mathrm{R}-\mathrm{CC}$ & 481.3 & 9 \\
\hline $26 \mathrm{R}-1,29-30$ & 481.4 & 8 \\
\hline $26 \mathrm{R}-1,78-79$ & 481.8 & 7 \\
\hline $26 \mathrm{R}-1,85-86$ & 482.0 & 8 \\
\hline $26 \mathrm{R}-2,34-35$ & 483.1 & 5 \\
\hline $26 \mathrm{R}-2,63-64$ & 483.4 & 5 \\
\hline $26 \mathrm{R}-2,111-114$ & 484.0 & 9 \\
\hline $26 \mathrm{R}-2,146-147$ & 484.4 & 5 \\
\hline $26 \mathrm{R}-3,4-6$ & 484.7 & 8 \\
\hline $26 \mathrm{R}-3,30-32$ & 484.9 & 6 \\
\hline $26 \mathrm{R}-3,132-133$ & 485.9 & 5 \\
\hline $26 \mathrm{R}-4,37-39$ & 486.2 & 5 \\
\hline $26 \mathrm{R}-4,64-65$ & 486.4 & 8 \\
\hline $26 \mathrm{R}-4,70-72$ & 486.5 & 7 \\
\hline
\end{tabular}

\begin{tabular}{|c|c|c|}
\hline $\begin{array}{l}\text { Core, section, } \\
\text { interval }(\mathrm{cm})\end{array}$ & $\begin{array}{l}\text { Depth } \\
\text { (mbsf) }\end{array}$ & $\begin{array}{l}\text { Abundance } \\
\text { code }\end{array}$ \\
\hline $26 \mathrm{R}-5,52-53$ & 487.7 & 9 \\
\hline $26 \mathrm{R}-5,68-70$ & 487.9 & 7 \\
\hline $26 \mathrm{R}-6,64-66$ & 489.6 & 8 \\
\hline $26 \mathrm{R}-6.85-87$ & 489.8 & 9 \\
\hline $26 \mathrm{R}-6,94-95$ & 490.0 & 8 \\
\hline $26 \mathrm{R}-7,17-19$ & 490.4 & 8 \\
\hline $26 \mathrm{R}-7,34-36$ & 490.5 & 9 \\
\hline $26 \mathrm{R}-\mathrm{CC}$ & 490.7 & 7 \\
\hline 27R-1, 93-96 & 491.6 & 8 \\
\hline $27 \mathrm{R}-1,139-141$ & 492.1 & 7 \\
\hline $27 \mathrm{R}-2,35-37$ & 492.6 & 9 \\
\hline $27 \mathrm{R}-2,45-46$ & 492.7 & 8 \\
\hline $27 \mathrm{R}-2,82-83$ & 492.9 & $\stackrel{9}{9}$ \\
\hline $27 \mathrm{R}-2,85-86$ & 492.9 & 9 \\
\hline $27 \mathrm{R}-2,93-96$ & 493.0 & 9 \\
\hline $27 \mathrm{R}-2,120-121$ & 493.4 & 9 \\
\hline $27 \mathrm{R}-3,28-30$ & 494.0 & 9 \\
\hline $27 \mathrm{R}-3,37-37$ & 494.2 & 9 \\
\hline $27 \mathrm{R}-3,55-56$ & 494.3 & 9 \\
\hline $27 \mathrm{R}-3,56-57$ & 494.6 & 4 \\
\hline 27R-3,96-97 & 494.7 & 7 \\
\hline $27 \mathrm{R}-3,137-138$ & 495.1 & 2 \\
\hline $27 \mathrm{R}-4,9-11$ & 495.3 & 1 \\
\hline $27 \mathrm{R}-4,127-129$ & 499.5 & 5 \\
\hline $27 \mathrm{R}-5,10-11$ & 496.8 & 6 \\
\hline $27 \mathrm{R}-5,56-58$ & 497.3 & 4 \\
\hline $27 \mathrm{R}-5,76-78$ & 497.5 & 6 \\
\hline $27 \mathrm{R}-5,80-8 \mathrm{I}$ & 497.6 & 5 \\
\hline $27 \mathrm{R}-5,147-148$ & 498.2 & 1 \\
\hline $27 \mathrm{R}-6,81-83$ & 499.0 & $i$ \\
\hline $27 \mathrm{R}-6,86-88$ & 499.1 & 1 \\
\hline $27 \mathrm{R}-\mathrm{CC}$ & 500.3 & 1 \\
\hline $28 \mathrm{R}-1,70-71$ & 501.0 & $i$ \\
\hline $28 \mathrm{R}-1,84-86$ & 501.1 & 1 \\
\hline $28 \mathrm{R}-1,102-103$ & 501.3 & 1 \\
\hline $28 \mathrm{R}-2,27-30$ & 502.1 & i \\
\hline $28 \mathrm{R}-2,47-48$ & 502.3 & 1 \\
\hline $28 \mathrm{R}-2,99-100$ & 502.8 & 1 \\
\hline $28 R-2,136-137$ & 503.1 & 1 \\
\hline $28 \mathrm{R}-3,23-24$ & 503.5 & 1 \\
\hline $28 \mathrm{R}-3,82-84$ & 504.1 & i \\
\hline $28 R-4,16-17$ & 505.0 & 1 \\
\hline $28 R-4,68-69$ & 505.5 & 1 \\
\hline $28 R-4,105-106$ & 505.9 & 1 \\
\hline $28 \mathrm{R}-6,6-8$ & 508.4 & 1 \\
\hline $29 \mathrm{R}-1,65-67$ & 510.6 & i \\
\hline $29 \mathrm{R}-2,103-104$ & 512.4 & 1 \\
\hline $29 \mathrm{R}-3,48-49$ & 513.4 & 1 \\
\hline $29 \mathrm{R}-3,84-86$ & 513.7 & 1 \\
\hline $29 R-4,122-123$ & 515.6 & $i$ \\
\hline $29 \mathrm{R}-4,150-151$ & 515.9 & 1 \\
\hline $30 \mathrm{R}-1,71-72$ & 520.2 & \\
\hline $30 \mathrm{R}-2,88-89$ & 521.9 & 2 \\
\hline $30 \mathrm{R}-2,93-94$ & 522.0 & 2 \\
\hline $30 R-5,43-44$ & 525.9 & 1 \\
\hline $32 \mathrm{R}-1,20-21$ & 539.0 & 3 \\
\hline $32 \mathrm{R}-1,54-55$ & 539.3 & 2 \\
\hline $32 \mathrm{R}-1,150-151$ & 540.3 & 1 \\
\hline $32 \mathrm{R}-2,27-28$ & 540.6 & 2 \\
\hline $32 R-2,65-66$ & 541.0 & 2 \\
\hline $32 \mathrm{R}-2,73-74$ & 541.1 & 1 \\
\hline $32 \mathrm{R}-2,85-86$ & 541.3 & i \\
\hline $32 R-3,61-62$ & 542.4 & 4 \\
\hline $32 R-4,30-31$ & 543.6 & 1 \\
\hline $32 \mathrm{R}-\mathrm{CC}$ & 548.4 & 5 \\
\hline $33 \mathrm{R}-1,8-9$ & 548.5 & 2 \\
\hline $34 \mathrm{R}-\mathrm{CC}$ & 567.7 & 1 \\
\hline $36 \mathrm{R}-\mathrm{CC}$ & 587.1 & 1 \\
\hline $38 \mathrm{R}-\mathrm{CC}$ & 606.4 & 1 \\
\hline $41 \mathrm{R}-\mathrm{CC}$ & 635.4 & 2 \\
\hline $42 \mathrm{R}-\mathrm{CC}$ & 645.1 & 1 \\
\hline $43 \mathrm{R}-\mathrm{CC}$ & 654.7 & 1 \\
\hline $45 \mathrm{R}-\mathrm{CC}$ & 664.4 & i \\
\hline
\end{tabular}

Note: Abundance codes defined in Table 1. Not all barren samples tabulated.

Comments: This taxon is closely akin to A. undulatus and may not justify independent species rank. Nevertheless, it is clearly identifiable and seems to have widespread distribution and stratigraphic utility, therefore the name is retained.

Actinoptychus senarius (Ehrenberg) Ehrenberg (1843) pl. 27, fig. 27

Actinoptychus thumii (Schmidt) Hanna (1932) pl. 4, figs 3, 4; Dzinoridze et al. (1978) pl. 12, figs. 1-3 
Table 5. Paleogene diatom occurrence and abundance in Hole 913B.

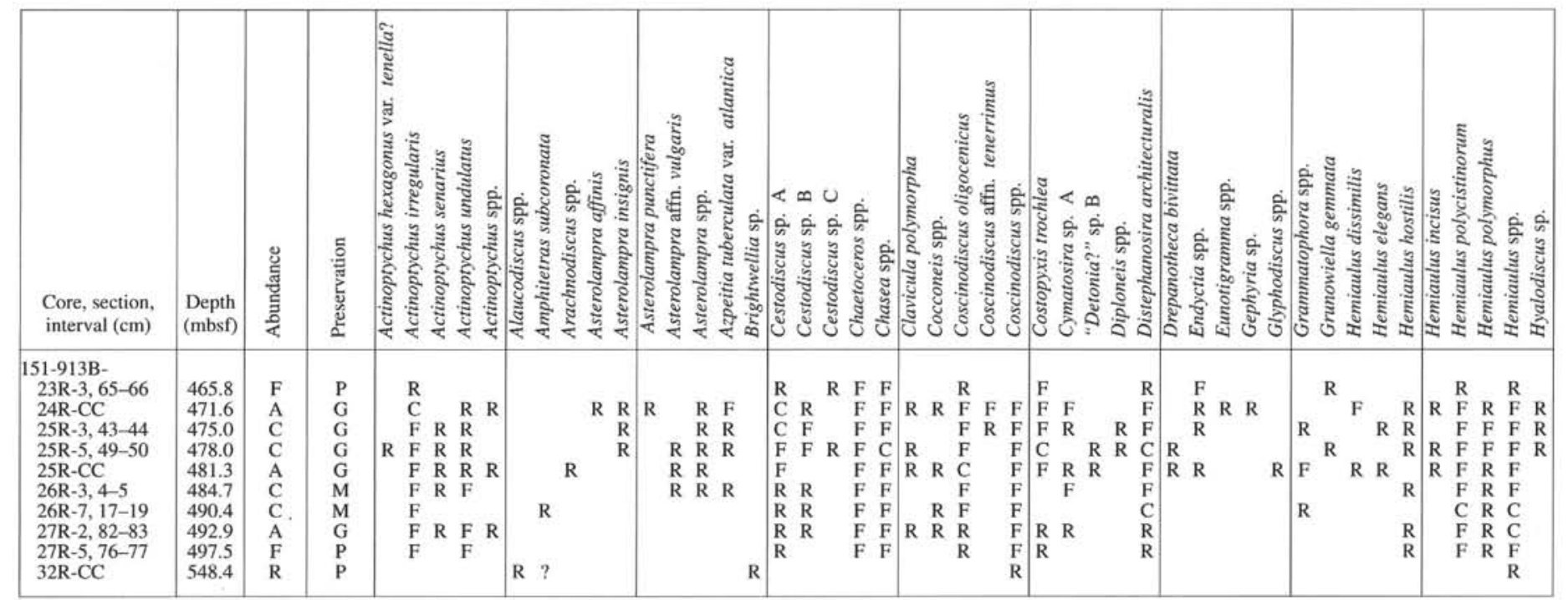

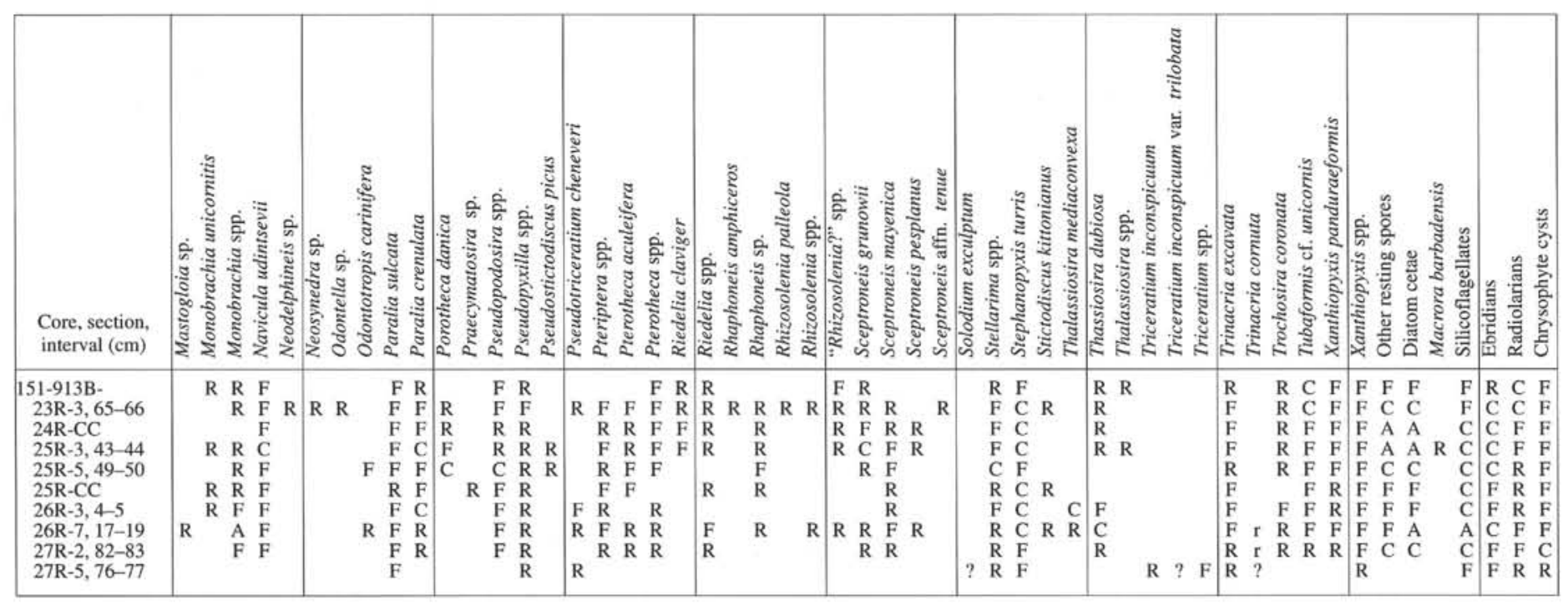

Note: Codes defined in Table 1 
Actinoptychus undulatus (Bailey) Ralfs in Prichard (1861) pl. 5, fig, 88; Dzinoridze et al. (1978) pl. 6, figs. 1-5, pl. 12, fig. 4. (Pl. 6, Fig. 16)

Actinoptychus sp. A (Pl. 8, Fig. 1)

Actinoptychus spp.

Amphitetras sp. (Pl. 8, Fig. 6)

Synonym: Biddulphia decepiens sensu Gleser (1968) pl. 2, fig. 7.

Anaulus sp. (PI. 8, Fig. 16)

Anuloplicata ornata (Grunow) Gleser in Gleser et al. (1992) pl. 49, figs. 1-6 Arachnodiscus spp.

Asterolampra affinis Greville (1862) pl. 7, figs. 7-9; Hendy and Sims (1990) pl. 3, figs. 13-15. (Pl. 6, Fig. 5)

Asterolampra insignis Schmidt (1874) pl. 137, figs. 1-3. (Pl. 6, Figs. 4, 20)

Asterolampra punctifera (Grove) Hanna (1927) pl. 17, fig. 3. (Pl. 6, Fig., 15; Pl. 8, Fig. 13)

Asterolampra spp. (fragments)

Asteromphalus flabellatus (Brébisson) Greville (1859) pl. 7, figs. 4, 5. (Pl. 6, Fig. 7)

Synonym: Asteromphalus robusta? sensu Schrader and Fenner (1976) pl. 21 , fig. 9.

Asteromphalus oligocenicus Schrader and Fenner (1976) pl. 21, figs. 8, 13, 14; pl. 28, fig. 1. (PI. 6, Fig. 14)

Asteromphalus? affn. symmetricus? Schrader and Fenner (1976) pl. 21, figs. 7, 10-12. (PI. 8, Fig. 13)

Comments: Only two specimens were observed and identification is not certain. If the tentative identification is correct, then the stratigraphic range of A. symmetricus is extended downward into the lower Oligocene.

Aulacodiscus spp.

Azpeitia oligocaenica (Jousé) Sims in Fryxell et al. (1986) pl. 16, figs. 6-8. (Pl. 5, Fig. 6)

Azpeitia tuberculata var. atlantica (Gleser and Jousé) Sims in Fryxell et al. (1986) (Pl. 6, Fig. 1)

Basionym: Coscinodiscus tuberculatus var. atlantica Jousé (1973) pl. 1, figs. 14-18; Schrader and Fenner (1976) pl. 14, fig. 4; pl. 29, figs. 3, $5,6,12,13$.

Biddulphia spp.

Brightwellia sp. (Pl. 8, Fig. 5)

Cavitatus jouseanus (Sheshukova) Williams (1989) p. 260; Akiba et al. (1993) fig. 6: 19, 20. (Pl. 2, Figs. 18-20)

Basionym: Synedra jouseana Sheshukova-Poretskaya (1962) fig. 4.

Cestodiscus pulchellus var. novazealandica Grove in Schmidt (1890) pl. 148, fig. 7; pl. 163, figs. 8, 10. (Pl. 5, Fig. 3)

Cestodiscus sp. A (Pl. 5, Figs. 2, 8, 12, 13)

Synonyms: Cestodiscus muhinae (sic) Schrader and Fenner (1976) pl. 29, fig. 4 (not pl. 27, figs. 11, 12); Cestodiscus sp. 9 Baldauf and Monjanel (1989) pl. 1, figs. 2 , 5 ; pl. 2 , fig. 9

Comments: Differs from $C$. mukhinae Jousé in pattern of areolae and marginal structure, but may be closely related.

Cestodiscus sp. B (Pl. 5, Figs. 4, 5)

Synonym: Cestodiscus muhinae (sic) Schrader and Fenner (1976) pl. 27, figs. 11,12 (not pl. 29 fig. 4). Cells small, finely areolate.

Cestodiscus sp. C (Pl. 5, Figs. 7, 11)

Comments: Cells small, coarse, with slight central depression.

Chaetoceros spp.

Comments: dominantly resting spores and or setae.

Chasea spp.

Clavicula polymorpha Grunow and Pantocsek in Pantocsek (1886) p. 37. (Pl. 2, Fig. 21)

Synonym: Synedra polymorpha Schrader (1969).

Cocconeis spp.
Coscinodiscus aff. tenerrimus Dzinoridze et al. (1978) pl. 3, figs, 4a, b. (Pl. 7 Fig. 1)

Coscinodiscus bulliens Schmidt (1878) in Schmidt et al. (1878) pl. 61, fig. 11 Coscinodiscus marginatus Ehrenberg (1854) pl. 18, fig. 44

Coscinodiscus oligocenicus Jousé (1973) pl. 1, figs. 6-8, 16. (Pl. 8, Fig. 7)

Coscinodiscus radiatus Ehrenberg (1841) pl. 3, figs. la-c

Coscinodiscus spp.

Comments: Includes several rare large, long-ranging (extant or non-agediagnostic) taxa.

Costopyxis trochlea (Hanna) Strelnikova in Gleser et al. (1992) pl. 32, figs. 17, 18. (P1. 8, Figs. 8-10)

Basionym: Trochosira trochlea Hanna (1927) pl. 21, figs. 8, 9

Synonym: Pterotheca sp. 1 of Schrader and Fenner (1976) pl. 35, figs. $15-19$.

Craspedodiscus moelleri Schmidt (1893) pl. 184, fig. 3 (only fragments encountered)

Craspedodiscus? sp. A (Pl. 5, Fig. 10)

Cyclotella sp. A (PI. 8, Fig. 15)

Comments: Compare with "Genus and Species unidentified 1" of Schrader and Fenner (1976) pl. 15, fig. 4., and Cyclotella affn. ovata Tynni (1982) pl. 17, fig. 4.

Cymatosira compacta Schrader and Fenner (1976) pl. 8, figs. 22, 25; pl. 25 , figs. 30-32. (Pl. 3, Fig. 7)

Cymatosira praecompacta Schrader and Fenner (1976) pl. 8, figs. 19, 23, 24; pl. 25, figs. 14, 29. (Pl. 3, Figs. 2-6, 9-13)

Cymatosira sp. A

Synonyms: "Genus and Species unidentified 10" of Schrader and Fenner (1976) pl. 22, fig. 8; Cymatosira sp. of Schrader and Fenner (1976) pl. 25, figs. 25, 26. (Pl. 3, Figs. 14-16)

Delphineis spp.

"Detonia?" sp. A. This and the following species ("Detonia?" sp. B) belong to an undescribed genus in the family Rhaphoneidaceae. The genus is closely related to Detonia, Diplomenora, and Rhaphoneis. Further taxonomic investigaton is in progress. (Pl. 2, Figs. 1-5).

“Detonia?” sp. B. See above. (Pl. 2., Figs. 10, 11).

Diploneis spp.

Distephanosira architecturalis (Brun) Gleser et al. (1992) (Pl. 4, Figs. 14-17) Basionym: Melosira architecturalis.

Comments: Has been referred to as Paralia architecturalis in the literature (e.g., Harwood and Maruyama, 1992), although there has never been a formal transfer to that genus. The genus Distephanosira was recently erected to include this taxon (Gleser et al., 1992).

Drepanotheca bivittata (Grunow and Pantocsek) Schrader (1969) (Pl. 2, Fig. 15)

Basionym: Eunotigramma bivittata Grunow and Pantocsek in Pantocsek (1886) pl. 26, fig. 247

Endictya spp.

Eunotogramma spp. (Pl. 2, Fig. 25)

Eurossia irregularis (Greville) Sims in Mahood et al. (1993) figs. 23, 24, 3136, 65, 74, 75. (Pl. 6, Fig. 1)

Basionym: Triceratium irregulare Greville (1864) pl. 12, fig. 5.

Synonyms: Triceratium polymorphus Harwood and Maruyama (1992) pl.

1, figs. 1, 2; Triceratium sp. 2 Baldauf and Monjanel (1989) pl. 1, fig

9; Triceratium schultzii Jousé sensu Schrader and Fenner (1976) pl.

27 , figs. 14, 15 .

Eurossia irregularis var. incurvatus Sims in Mahood et al. (1993) figs. 3742, 66, 67. (Pl. 6, Fig. 2)

Synonyms: Triceratium macroporum Hajós sensu Gombos and Ciesielski (1983) pl. 17, fig. 6; Triceratium cf. megapora Hajós sensu Baldauf and Monjanel (1989) pl. 1, fig. 10; Triceratium latepes Fenner in Schrader and Fenner (1976) pl. 26, fig. 12

"Fragilaria" spp., including "Fragilaria" sp. A 
Comments: The following two taxa are assigned to the genus Fragilaria although it is recognized that their proper positions are likely elsewhere, requiring further investigation. (Pl. 2, Fig. 26).

"Fragilaria" miocenica Jousé (after Gleser et al,, 1974, pl. 64, figs. 11A, B). (Pl. 2, Fig. 27)

Gephyria sp.

Glyphodiscus sp.

Goniothecium coronatum Fenner in Schrader and Fenner (1976) pl. 44, fig. 7

Goniothecium decoratum Brun (1891) pl. 37, fig. 6; Schrader and Fenner (1976) pl. 6, figs. 3, 5, pl. 37, figs. 1-5, 11-14; Dzinoridze et al. (1978) pl. 15 , figs. $1-5$

Goniothecium odontella Ehrenberg (1854) pl. 18, fig. 94; pl. 33, fig. 15; Schrader and Fenner (1976) pl. 6, figs. 1, 2, 4

Grammatophora spp. (PI. 2, Fig. 14)

Grunoviella gemmata (Grunow) Van Heurck (1896) (Pl. 1, Fig. 1)

Comments: Van Heurck (1896) described this genus to account for Sceptroneis? gemmata Grunow. Hustedt (1959) later transferred it to Opephora. According to the generic description in Round et al. (1990), Opephora lacks marginal spines, which would thus exclude $G$. gemmata. G. gemmata is often still assigned to Sceptroneis (e.g., Fenner, 1994), but structural differences in the areolae exclude it from this genus.

Hemiaulus danicus Grunow in Cleve and Möller (1878); Grunow (1884) pl. 2, fig. 40

Hemiaulus dissimilis Grove and Sturt (1887) pl. 13, fig. 43

Hemiaulus elegans (Heiberg) Grunow (1884) p. 14. (Pl. 7, Fig. 6)

Hemiaulus horridus group (Pl. 7, Figs. 4, 5)

Hemiaulus hostilis Heiberg (1863) pl. 1, fig. 11

Hemiaulus incisus Hajós (1976) pl. 23, figs. 4-9. (Pl. 7, Figs. 7, 12, 15, 16)

Hemiaulus kittonii Grunow in Van Heurck (1883) pl. 106, figs. 6-9; Schrader and Fenner (1976) pl. 10, fig. 19

Hemiaulus polycistinorum Ehrenberg (1854) pl. 36, figs. 43a, b. (Pl. 7, Fig. 13)

Hemiaulus spp.

Hyalodiscus subtilus Bailey (1854) pl. 1, fig. 12

Hyalodiscus spp.

Isthmia sp.

Kannoa sp. (Pl. 2, Fig. 12)

Licmophora? sp. (Pl. 4, Fig. 21)

Lithodesmium rotunda Schrader in Schrader and Fenner (1976) pl. 11, fig. 5

Mastagloia spp.

Melosira ignota Rubina (after Gleser et al., 1992, pl. 66, figs. 6-12; Gleser and Posnova, 1974, pl. 61, figs. 4a-4c). (Pl. 4, Figs. 10-13)

Comments: Not often reported, this very distinctive diatom, known mostly from Siberian Arctic deposits, is occasionally common in lower Oligocene sediments of Site 908. Areolae on the valve face are fine, arranged in a distinctive "eccentric-concentric" pattern across the valve face. Areolae are densely packed and highly ordered across the deep mantle. M. ignota is similar to Distephanosira architecturalis, but it lacks the central hyaline area of $D$. architecturalis, and linking structures are reduced in $M$. ignota. $M$. ignota has a deeper mantle than $D$. architecturalis and finer areolation on the valve face and mantle. May be synonymous with Melosira excentrica Pantocsek (1892; pl. 6, fig. 90). This diatom may be restricted to circum-arctic sediments. Rubina (1962) described Melosira ignota as occurring in nonmarine deposits, although its common occurrence at Site 908 suggests a marginal marine affinity.

Monobrachia unicornuta Schrader and Fenner (1976) pl. 42, figs. 13, 14. (PI. 3, Fig. 27)

\section{Monobrachia spp. (Pl. 3, Fig. 23)}

Navicula udintsevii Schrader and Fenner (1976) pl. 22, fig. 33; pl. 24, fig. 2. (PI. 2, Figs. 23, 24)

Comments: Since its description, this taxon has been shown have a bipolar distribution (e. g., Harwood and Maruyama, 1992) in late Eocene to early Oligocene sediments.

Neodelphineis pelagica Takano (1982); Round et al. (1990) p. 412, figs. a-i. (Pl. 2, Fig. 17)

Synonym: Fragilaria voeringia Fenner in Schrader and Fenner (1976) pl. 25 , figs. $22-24$.

Comments: This diatom fits the generic description of the marine epiphytic genus Neodelphineis, according to Round et al. (1990), rather than the exclusively freshwater Fragilaria.

Neosynedra sp.

Odontotropis carinata Grunow (1884) p. 59. (Pl. 7, Figs. 8, 14)

Comments: This large, distinctive neritic diatom, probably a resting spore, is well known in Paleocene to lower Eocene deposits but occurs sporadically into lower Oligocene? strata. Occurrences in Sample 151-913B-25R-CC are high enough to rule out reworking, particularly because other reworked lower Paleogene taxa are quite rare.

Paralia crenulata (Grunow) Gleser in Gleser et al. (1992) pl. 41, figs. 1-8. (Pl. 4, Figs. 23, 24)

Basionym: Paralia sulcata var. crenulata Grunow (1884) pl. 5, fig. 34.

Synonym: Melosira sulcata var. crenulata.

Paralia siberica Schmidt (1892) pl. 177, figs. 12-22.

Comments: Rare in Hole 908A, tabulated with Paralia crenulata.

Paralia sulcata (Ehrenberg) Cleve (1873) p. 7

Pleurosigma planktonica Schrader in Schrader and Fenner (1976) pl. 5, fig. 25

Porotheca danica (Grunow) Fenner (1994) pl. 4, figs. 16, 17; pl. 15, figs. 1-6

Praecymatosira sp. (Pl. 3, Fig. 8)

Pseudopodosira bella Gleser and Posnova (1964) fig. 1

Pseudopodosira spp.

Pseudopyxilla spp.

Comments: At least eight described Pseudopyxilla species are present, but many or most may be resting spores of other taxa (See Homann, 1991). Pseudopyxilla species are not differentiated in this study.

Pseudostictodiscus picus Hanna (1927) pl. 3, figs. 1-4; Schrader and Fenner (1976) pl. 35, figs. 25, 26. (Pl. 6, Fig. 8)

Pseudotriceratium cheneveri (Meister) Gleser et al. (1974); Strelnikova (1960) pl. 9, fig. 6

Pseudotriceratium radiosoreticulatum Grunow in Van Heurck et al. (1883) pl. 112, fig. 5. (Pl. 6, Fig. 3)

Synonym: Pseudotriceratium affn. cheneveri Schrader and Fenner (1976) pl. 26, figs 6, 8, 9.

Pteriptera spp,

Pterotheca aculeifera Grunow in Van Heurck (1882), Van Heurck (1896) pl. 430, fig. 151. (Pl. 8, Fig. 11)

Pterotheca spp.

Pyxilla oligocaenica Jousé (1955) pl. 6, figs. 5, 6; pl. 7, figs. 3, 4. (Pl. 3, Fig. 17)

Synonym: Pyrgupyxis oligocaenica Schrader and Fenner (1976) pl. 43, figs. 20, 27 (see discussion in Gombos and Ciesielski, 1983).

Pyxilla oligocaenica var. tenuis Jousé (1955) pl. 6, figs. 4, 7; pl. 7, figs. 1-2. (Pl. 3, Fig. 18)

Synonym: Pyrgupyxis oligocaenica Schrader and Fenner (1976) pl. 43, fig. 18.

Rhabdonema sp.

Rhaphoneis affn. amphiceros (PI. 2, Figs. 7, 8)

Comments: Strongly capitate. Structural features of areolae and labiate processes similar to R. amphiceros (Ehrenberg) Ehrenberg (1844). 
Rhaphoneis angulata Fenner in Schrader and Fenner (1976) pl. 7, fig. 18. (Pl. 2, Fig. 9)

Rhaphoneis elongata (Schrader) Andrews (1975) pl. 1, fig. 2

Rhaphoneis spp.

Rhizosolenia oligocaenica Schrader (1976) pl. 9, fig. 7. (Pl. 3, Figs. 28, 29)

Synonym: Rhizosolenia gravida Gombos and Ciesielski (1983), pl. 11, figs. 1-7; Fenner (1985) pl. 11, fig. 18.

Rhizosolenia oligocaenica var. styliforma n. var. (Pl. 3, Figs. 24-26)

Description: The apical spine of Rhizosolenia oligocaenica var. stylifor$m a \mathrm{n}$. var. differs from that of Rhizosolenia oligocaenica Schrader by the presence of winglike siliceous projections that reach about twothirds from the base of the spine to the tip. The wing is thicker and wider on one side of the spine than the other. Although no whole valves were observed, the size, shape, and areolar pattern of the deep Rhizosolenia mantle follow that of $R$. oligocaenica early in its range.

Holotype: (RPS95-151-V1), Sample 151-908A-21X-3, 30-31 cm, PI. 3, Fig. 24.

Rhizosolenia oligocaenica var. A. (Pl. 3, Figs. 21, 22)

Comments: Similar to Rhizosolenia oligocaenica Schrader, except that the apical spine is large and strongly curved. Compare Rhizosolenia sp. 1 of Fenner (1977) pl. 20, fig. 9.

Rhizosolenia palleola Schrader and Fenner (1976) pl. 41, fig. 11

"Rhizosolenia?" spp., including "Rhizosolenia?" sp. A (PI. 3, Figs. 20, 30)

Comments: The taxa below referred to as "Rhizosolenia?" are in a problematic group, probably related to Proboscia Sündstrom, and certainly not related to the modern concept of Rhizosolenia Ehrenberg. This is a large group, with a long stratigraphic record and many formally or informally described fossil species. Taxonomic evaluation is further complicated by the fact that whole specimens are rarely preserved, which may lead to confusion with fragments of Riedelia or other genera. Detailed taxonomic evaluation of this genus and related or morphologically similar genera is badly needed. For the present report, in an effort to avoid further complications, Rhizosolenia is retained for identification purposes.

"Rhizosolenia?" pokrovskayae (Jousé) Strelnikova (1964) pl. 28, figs. 1-9; Schrader and Fenner (1976) pl. 7, figs. 8, 9. (Pl. 3, Fig. 19)

Riedelia claviger (Schmidt) Schrader and Fenner (1976) pl. 41, figs. 6-8, 9; pl. 42, figs. 3, 4, 10, 11, 15. (Pl. 3, Fig. 31)

Basionym: Hemiaulus claviger Schmidt (1888) pl. 143, figs. 5, 6.

Riedelia spp.

Rocella praenitida (Fenner) Fenner in Kim and Barron (1986) pl. 4, fig. 3. (PI. 7, Figs. 9-11)

Basionym: Coscinodiscus praenitidus Fenner in Schrader and Fenner (1976) pl. 14, figs. $7-9$, 12; pl. 27, fig. 8 ; pl. 35 , fig. 24 ; pl. 36 , fig. 5.

Rouxia sp. A

Comments: Resembles $R$. obesa, a widespread lower Oligocene taxon described from DSDP Leg 38 material (Schrader and Fenner, 1976), but Rouxia sp. A has a more tapered outline. (Pl. 2, Fig. 22).

Rutilaria areolata Sheshukova in Gleser et al. (1974) pl. 33, fig. 3a, b; Schrader and Fenner (1976) pl. 8, figs. 11, 12; pl. 37, fig. 16. (Pl. 3, Fig. 1)

Sceptroneis fennerae n. sp. (Pl. 1, Figs. 3-6)

Description: Valve face slightly arched, apicies capitate, center swollen. Small but prominent labiate process at center of head pole, beneath an apical pore field. Pore field is surrounded at the apex by a single row of punctae that are supported by thick siliceous struts. Foot pole rounded, headpole flattened to broadly rounded, particularly in smaller specimens. Length overall, $22-44 \mu \mathrm{m}$, width in the center 9-11 $\mu \mathrm{m}$. Head pole 6-7 $\mu \mathrm{m}$ wide, foot pole 5-6 $\mu \mathrm{m}$ wide. Areolae punctate with complex rotae, 5 in $10 \mu \mathrm{m}$; striae, 4 in $10 \mu \mathrm{m}$. Closely related to $S$. humuncia var. rondipoda. The Sceptroneis species complex includes many related other forms (e.g., Pl. 1, Figs. 2, 15), but the characteristics of $S$. fennerae sensu stricto are consistent within the population.

Holotype: (RPS95-151-S1), Sample 151-908A-25R-CC, PI. 1, Fig. 4. Named in honor of Julianne Fenner.

Sceptroneis grunowii Anissimova in Proschkina-Lavrenko (1949) p. 217. (Pl.

1, Figs. 25, 26)
Comments: Slender outline in the Eocene, becoming progressively broader through the early Oligocene. $S$. pupa diverges from the $S$. grunowii lineage in the early late Oligocene.

Sceptroneis humuncia var. rondipoda $\mathrm{n}$. var. (Pl. 1, Figs. 7-9, 14)

Description: The main morphologic difference between $S$. humuncia var. rondipoda and S. humuncia Schrader and Fenner (1976, pl. 2, figs. 57 ; pl. 24 , figs. 17,26 ) sensu stricto (s.s.), is that the foot pole tapers to a rounded apex, instead of the flattened to concave foot pole apex of $S$. humuncia s.s. The minimum and maximum length of $S$. humuncia var. rondipoda $(75-135 \mu \mathrm{m})$ both exceed the published limits for $S$. humancia $(90-106 \mu \mathrm{m})$. The head pole of $S$. humuncia var. rondipoda is often less concave than that of the nominate variety. Specimens are slightly to moderately twisted. Micrographs of the nominate variety in Schrader and Fenner (1976) suggest that twisting occurs in some specimens of $S$. humuncia s.s. Striae, punctae, and general shape are consistent features in the lineage. $S$. humuncia var. rondipoda occurs further down in the stratigraphic column than $S$. humuncia s.s., implying that $S$. humuncia evolved from variety rondipoda. $S$. humuncia var. rondipoda is related to Sceptroneis fennerae, both morphologically and stratigraphically.

Holotype: (RPS95-151-V2), Sample 151-908A-25X-CC, Pl. 1, Fig. 7.

Sceptroneis mayenica Fenner in Schrader and Fenner (1976) pl. 22, figs. 22

25 ; pl. 23, figs. $1-4$; pl. 25, figs. 6, 8. (Pl. 1, Fig. 27)

Sceptroneis pesplanus Schrader and Fenner (1976) pl. 22, figs. 30, 31; pl. 25 , figs. 10,11

Sceptroneis praecaducea Hajós and Stradner (1975) pl. 13, figs. 13, 14; pl. 14, figs. 1-4. (Pl. 1, Figs 10, 11, 16)

Comments: All specimens observed have a strongly twisted valve. This is a consistent enough feature that varietal status may be warranted.

Sceptroneis propinqua Schrader and Fenner (1976) pl. 4, figs. 1-8. (Pl. 2, Fig. 6)

Sceptroneis pupa Schrader and Fenner (1976) pl. 22, figs. 17-21; pl. 24, figs 11-13. (Pl. 1, Figs. 22, 23)

Sceptroneis pupa/grunowii transitional forms. (PI. 1, Figs. 18-21)

Sceptroneis talwanii Schrader and Fenner (1976) pl. 24, figs. 28-30

Sceptroneis tenue Schrader and Fenner (1976) pl. 3, figs. 2-4; pl. 25, figs 12, 22, 24. (Pl. 1, Fig. 13)

Sceptroneis affn. tenue

Comments: Found almost exclusively as fragments; thus, identification is often uncertain.

Sceptroneis vermiformis Schrader in Schrader and Fenner (1976) pl. 22, fig. 29 ; pl. 25 , figs. $1-4$

Sceptroneis spp. (Pl. 1, Figs. 12, 24; Pl. 2, Fig. 16)

Sheshukovia spp.

"Skeletonema" utriculosa Brun (1891) pl. 11, figs. 1a, b; Sims (1994) figs. 33-36, 51. (Pl. 4, Fig. 26)

Comments: See Sims (1994) for a discussion of the taxonomic position of this diatom.

Solium exculptum Heiberg (1863) pl. 4, fig. 10

Comments: Documented as reworked specimens.

Stellarima spp.

Stephanogonia polycantha Forti (1913) pl. 12, fig. 11

Stephanopyxis turris group (Greville and Arnott) Ralfs in Pritchard (1861) pl. 5 , fig. 74

Stephanopyxis spp.

Comments: Category includes $S$. barbadensis, $S$. hyalomarginata, $S$. grossecellulata, S. grunowii, S. marginata, S. schenkii?, S. turris, and possibly others.

Stictodiscus kittonianus Greville (1861) pl. 10, figs. 2, 3

Stictodiscus nitidus (Grove and Sturt) Schmidt (1888) pl. 131, figs. 7, 8. (Pl. 5, Fig. 14)

“Synedra?" sp. 1 of Schrader and Fenner (1976) pl. 24, figs. 7, 8. (Pl. 2, Fig. 13) 
Tetracyclus spp.

Thalassiosira dubiosa Schrader and Fenner (1976) (Pl. 4, Figs. 6, 7)

Comments: This taxon is closely related to $T$. mediaconvexa, though is much smaller. Perhaps seasonal dimorphism of the same species (see discussion of $T$. nansenii)?

Thalassiosira mediaconvexa Schrader and Fenner (1976) pl. 36, fig. 1. (Pl. 4, Figs. 8, 9)

Thalassiosira nansenii n. sp. (PI. 4, Figs. 1-5)

Description: Originally described as Thalassiosira affn. irregulata by Schrader and Fenner (1976) pl. 20, fig. 13, from lower Miocene Norwegian-Greenland Sea strata, along with $T$. irregulata Schrader s.s. Subsequently $T$, affn. irregulata has been reported from high-latitude lower Oligocene to lower Miocene strata from the Norwegian-Greenland Sea (Schrader and Fenner, 1976; this study), the North Pacific (Barron, 1985) and Bering Sea (Barron, 1985; Baldauf and Barron, 1987, as Thalassiosira sp. aff. T. mediaconvexa), and the Antarctic (Harwood et al., 1989), and is sparse in low-latitude sediments (Kim and Barron, 1986), whereas Thalassiosira irregulata s.s. is more rare and of restricted distribution. The two taxa differ considerably in morphologic characteristics. The morphologic distinctiveness, bipolar distribution and stratigraphic utility of this taxon justifies the erection of a new species. T. nansenii is described based on taxonomic evaluation of specimens recovered from Site 908 upper lower Oligocene to lower upper Oligocene sediments and lower Miocene diatomite clasts recovered from beneath the Ross Ice Shelf, Antarctica (Harwood et al., 1989), with reference to figures published in the above references, representing many regions and ages. T. nansenii is characterized by a gently convex curvature of the valve (although Barron [1985] describes $T$. affn. irregulata as flat), with a ring of small, marginal spines (occluded processes?). Areolae are irregularly shaped and arranged radially, with distinctive bifurcation about half way across the valve. More coarsely areolate specimens show a rough fasciculation. Areolae are of similar size across most of the valve, with only slight reduction in size toward the margin. One marginal labiate process is often visible in the light microscope, especially in lightly silicified but well-preserved specimens. A few strutted processes are often visible in the central area, either as a small cluster or separately, between tightly spaced areolae. The overall cell size of $T$. nansenii ranges from $11 \mu \mathrm{m}$ to a maximum of about $45 \mu \mathrm{m}$.

Two populations of $T$. nansenii co-occur in material studied by the first author (including Oligocene sediments of ODP Site 908 (this study) and lower Miocene sediments from Antarctica [Harwood et al., 1989]). The populations are distinguished by coarse areolation (12-14 areolae in $10 \mu \mathrm{m}$ ), and a more fine areolation (15-18 areolae in 10 $\mu \mathrm{m})$. Most of the published illustrations of $T$. affn. irregulata are of the latter type. The coarsely areolate form is far more common in Site 908 sediments, but this could be a function of preferential preservation. We speculate that the two forms may represent seasonal dimorphism (summer and winter varieties). T. nansenii apparently evolved from $T$. mediaconvexa in the early Oligocene (see discussion below).

T. nansenii, a bipolar diatom, is named for the Norwegian "bipolar" explorer F. Nansen, in honor of the centenary of his historic voyage to the Arctic (1893-1896), via the Fram Strait, aboard the research ship Fram.

Holotype: (RPS95-151-S2), Sample 151-908A-26-3, 90-91 cm, Pl. 4, Fig. 2.

Thalassiosira nansenii/mediaconvexa transitional forms

Synonyms: Thalassiosira mediaconvexa sensu Yanagisawa and Suzuki (1987) pl. 1, fig. 10 (lower Oligocene of northern Japan); Thalassiosira aff. irregulata sensu Baldauf and Monjanel (1989) pl. 4, fig. 2 (lower Oligocene of Labrador Sea); Thalassiosira sp.? cf. mediaconvexa of Barron and Mahood (1993) pl. 4, figs. 9, 12 (lower Oligocene of Antarctic continental shelf); Thalassiosira mediaconversa of Gladenkov and Barron (1995) pl. 2, figs 8, 16 (lower Oligocene of north Pacific); Thalassiosira? sp. 1 of Fenner (1977) pl. 3, fig. 7 (lower Oligocene of tropical Atlantic).

Comments: Forms transitional between $T$. mediaconvexa, an Eocene form, and the Oligocene to lower Miocene T. nansenii occur in lower Oligocene strata, mostly in high, but rarely in low, latitudes. This diatom has been reported in the Antarctic (Barron and Mahood, 1993), northern Japan (Yanagisawa and Suzuki, 1987), and in the Labrador Sea (Baldauf and Monjanel, 1989), with one report in the low-latitude Atlantic (Fenner, 1977). Hole 908A records the replacement of transitional forms with exclusively $T$. nansenii s.s. in Core 151-908A-32X. Transitional forms are distinguished from $T$. nansenii s.s. by the distinctly raised center and relatively small and rounded areolae, which are characteristics of $T$. mediaconvexa. The change in slope of the valve face is about one-fourth the diameter away from the margin and is generally smooth, unlike $T$. mediaconvexa s.s., which usually has a more abrupt change in slope. Transitional forms also differ from $T$. mediaconvexa s.s in the reduction in size and prominence of the ring of occluded(?) marginal processes and the large marginal labiate process.

Thalassiosira sp. A (Pl. 5, Fig. 9)

Comments: Rare. Note strutted processes positioned between large areolae.

Thalassiosira sp. B (Pl. 5, Fig. 15)

Comments: Rare. Note large central labiate process.

Triceratium favus Ehrenberg (1841) pl. 4, fig. 10

Triceratium inconspicuum Greville (1861) pl. 8, fig. 10; Fenner (1978) pl. 30. (Pl. 8, Fig. 4)

Triceratium inconspicuum var. trilobata Fenner (1978) pl. 30, figs. 23-26 Synonym: Triceratium barbadensis Kanaya (1957) pl. 7, figs. 1-4.

Triceratium spp. (PI. 8, Figs. 2, 3)

Trinacria excavata Heiberg (1863) pl. 4, fig. 9

Trinacria cornuta (Schmidt) Sims and Ross (1988) pl. 1, figs. 1-9; pl. 12, figs. 78, 79. (Pl. 8, Fig. 14)

Synonym: Trinacria excavata forma tetragona Schmidt (1890) in Schmidt et al. (1890) pl. 152, figs. 26-28; Dzinoridze et al. (1978) pl. 10 , fig. 5 .

Trinacria affn. simulacrum Grove and Sturt (1887) pl. 13, fig. 46 Comments: Reworked fragments and rare whole specimens occur.

Trochosira coronata Schrader and Fenner (1976) pl. 29, figs. 9-11; pl. 35, figs. 7-13, 20, 21. (Pl. 4, Figs. 22, 25)

Trochosira spinosa Kitton (1871) pl. 14, figs. 6, 7. (Pl. 4, Figs. 18-20)

Tubaformis cf. unicornis Gombos (1983) pl. 5, figs. 1-6, pl. 6, figs. 1, 2. (Pl. 7, Figs. 2, 3)

Comments: Whole specimens have never been reported. This diatom has never been reported from the high northern latitudes, and has never been reported from deposits younger than middle Eocene. The high abundance of $T$. cf. unicornis in Site 913 Paleogene sediments rules out reworking from older sediments. Site 913 specimens have a large labiate process near the terminus of the "horns" (Pl. 7, Fig. 2).

Tumulopsis fogedi Hendy (1982) pl. 1, figs. 1-3

Synonym: Genus and Species unidentified 5 of Schrader and Fenner (1976) pl. 13, fig. 12.

Xanthiopyxis panduriformis Pantocsek (1886) pl. 29, fig. 297

Xanthiopyxis spp.

Incertae sedis

Macrora stella (Azpeitia) Hanna (1932) pl. 12, figs. 13, 14. (Pl. 6, Fig. 19)

Macrora barbadensis (Deflandre) Bukry (1977) pl. 2, figs. 3-8. (Pl. 6, Figs. $9,17,18)$

\section{ACKNOWLEDGMENTS}

This research was supported by funds from USSAC, the Institute of Earth Sciences, Uppsala University, and the Swedish Natural Science Research Council. We thank the Faculty of Science at Uppsala University for purchasing the microscope that made this study possible. Katarina Rosén-Lindberg provided drafting assistance, and 
Bertil Giös provided photographic services. Very helpful reviews, provided by Julianne Fenner, Lloyd Burckle, and Jack Baldauf, greatly improved the manuscript.

\section{REFERENCES}

Akiba, F., Hiramatsu, C., and Yanagisawa,Y., 1993. A Cenozoic diatom genus Cavitatus Williams; an emended description and two new biostratigraphically useful species, $C$. lanceolatus and $C$. rectus from Japan. Bull. Nat. Sci. Mus. Ser. C.: Geol. Paleontol. (Tokyo), 19:11-39.

Andrews, G.W., 1975. Taxonomy and stratigraphic occurrence of the marine diatom genus Raphoneis. Nova Hedwigia Beih., 53:193-222.

Bailey, J.W., 1854. Notes on new species and localities of microscopical organisms. Smithson. Contrib. Knowl., 7:1-16.

Baldauf, J., 1994. Middle Eocene through early Miocene diatom floral turnover. In Prothero, D. (Ed.), The Eocene-Oligocene Transition: New York (Columbia Univ. Press), 310-326.

Baldauf, J.G., and Barron, J.A., 1987. Oligocene marine diatoms recovered in dredge samples from the Navarin Basin province, Bering Sea. U.S. Geol. Surv. Bull., 1765.

1991. Diatom biostratigraphy: Kerguelen Plateau and Prydz Bay regions of the Southern Ocean. In Barron, J., Larsen, B., et al., Proc. ODP, Sci. Results, 119: College Station, TX (Ocean Drilling Program), 547-598.

Baldauf, J.G., and Monjanel, A.L., 1989. An Oligocene diatom biostratigraphy for the Labrador Sea: DSDP Site 112 and ODP Hole 647A. In Srivastava, S.P., Arthur, M.A., Clement, B., et al., Proc. ODP, Sci. Results, 105: College Station, TX (Ocean Drilling Program), 323-347.

Barron, J., Larsen, B., et al., 1989. Proc. ODP, Init. Repts., 119: College Station, TX (Ocean Drilling Program).

Barron, J., and Mahood, A., 1993. Exceptionally well-preserved early Oligocene diatoms from glacial sediments of Prydz Bay, East Antarctica. Micropaleontology, 39:29-45.

Barron, J.A., 1985. Miocene to Holocene planktic diatoms. In Bolli, H.M., Saunders, J.B., and Perch-Nielsen, K. (Eds.), Plankton Stratigraphy: Cambridge (Cambridge Univ. Press), 763-809.

Benda, L., 1972. The diatoms of the Moler Formation of Denmark (Lower Eocene): a preliminary report. Nova Hedwigia Beih., 39:251-266.

Brun, J., 1891. Diatomée éspeces rares ou nouvelles. Le Diatomiste, 1:1-30.

Bukry, D., 1977. Coccolith and silicoflagellate stratigraphy, South Atlantic Ocean, Deep Sea Drilling Project Leg 39. In Perch-Nielsen, K., Supko, P.R., et al., Init. Repts. DSDP, 39: Washington (U.S. Govt. Printing Office), 825-840.

Cleve, P.T., 1873. On diatoms from the Arctic Sea. Bihang till Kongl. Sven. Vetensk.-Akad. Handl., 1:1-28.

Cleve, P.T., and Möller, J. D., 1878. Diatoms (Exsiccata): Uppsala (Uppsala Univ.).

Dell'Agnese, D., and Clark, D.L., 1994. Siliceous microfossils from the warm Late Cretaceous and early Cenozoic Arctic Ocean. J. Paleontol., 68:31-46.

Dzinoridze, R.N., Jousé, A.P., Koroleva-Golikova, G.S., Kozlova, G.E., Nagaeva, G.S., Petrushevskaya, M.G., and Strelnikova, N.I., 1978. Diatom and radiolarian Cenozoic stratigraphy, Norwegian Basin; DSDP Leg 38. In Talwani, M., Udintsev, G., et al., Init. Repts. DSDP, 38, 39, 40, 41 (Suppl.): Washington (U.S. Govt. Printing Office), 289-427.

Ehrenberg, C.G., 1841. Verbreitung und Einfluß des mikroskopischen Lebens in Süd- und Nord-Amerika. Abh. K. Akad. Wiss. Berlin, 1:291-445.

, 1843. Über die weitere Entwickelung der Verbreitung und Einflusses des mikroskopischen Lebens in Afrika. Bericht über die zur Bekanntmachung geeigneten Verhandlungen der königl. preuss. Abh. Königl. Akad. Wiss. Berlin, 133-137.

_ 1844 . Mitteilung über zwei neue Lager von Gebirgsmassen aus Infusorien als Meeresabsatz in Nordamerika und eine Vergleichung derselben mit den organischen Kreidebildungen in Europa und Africa. $A b h$. Konigl. Akad. Wiss. Berlin, 57-97.

- 1854. Mikrogeologie: Leipzig (L. Voss).

Eldholm, O., Thiede, J., Taylor, E., et al., 1987. Proc. ODP, Init. Repts, 104: College Station, TX (Ocean Drilling Program).

Fenner, J., 1978. Cenozoic diatom biostratigraphy of the equatorial and southern Atlantic Ocean. In Perch-Nielsen, K., Supko, P.R., et al., Init. Repts. DSDP, 39 (Suppl.): Washington (U.S. Govt. Printing Office), 491624 .
1984. Eocene-Oligocene planktic diatom stratigraphy in the low latitudes and the high southern latitudes. Micropaleontology, 30:319342.

, 1985. Late Cretaceous to Oligocene planktic diatoms. In Bolli, H.M., Saunders, J.B., and Perch-Nielsen, K. (Eds.), Plankton Stratigraphy: Cambridge (Cambridge Univ. Press), 713-762.

1986. Information from diatom analysis concerning the EoceneOligocene boundary. In Pomerol, C.H., and Premoli-Silva, I. (Eds.), Terminal Eocene Events: Amsterdam (Elsevier), 283-288.

, 1994. Diatoms of the Fur Formation, their taxonomy and biostratigraphic interpretation: results from the Harre borehole, Denmark. Aarh. Geosci., 1:99-163.

Forti, D. A., 1913. Contribuzioni diatomologiche. Diagnoses Diatomacerum quarumdam fossilium italicarum. Atti Reale Inst. Veneto di Sci., Lett. ed Arti, 72:1567-1700.

Fryxell, G.A., Sims, P.A., and Watkins, T.P., 1986. Azpeitia (Bacillariophyceae): related genera and promorphology. Syst. Bot. Monogr., 13:174.

Gladenkov, A.Y., and Barron, J.A., 1995. Oligocene and early middle Miocene diatom biostratigraphy of Hole 884B. In Rea, D.K., Basov, I.A., Scholl, D.W., and Allan, J.F. (Eds.), Proc. ODP, Sci. Results, 145: College Station, TX (Ocean Drilling Program), 21-41.

Gleser, S.I., 1968. On the position of the genus Triceratium s. str. (Bacillariophyta) in the diatom system. Botan. J., USSR, 71:1543-1445. (in Russian)

Gleser, S.I., Jousé, A.P., Makarova, I.V., Proshkina-Lavrenko. A.I., and Sheshukova-Poretzkaya, V.S., 1974. The Diatoms of the USSR: Leningrad (Nauka). (in Russian)

Gleser, S.I., Makarova, I.V., Moisseeva, A.I., and Nikolaev, V., 1992. The Diatoms of the USSR, Fossil and Recent (Vol. 2): Stephanodiscaceae, Ectodictyonaceae, Paraliaceae, Radialiplicataceae, Pseudopodosiraceae, Trochosiraceae, Melosiraceae, Aulacosiraceae: St. Petersberg (Nauka). (in Russian)

Gleser, Z.I., and Posnova, A.N., 1964. Diatameae novae marinae ex eoceno Kazachstaniae occidentilis. Izd. Nauka, 59-66. (in Russian)

Gombos, A.M., Jr., 1983. Middle Eocene diatoms from the South Atlantic. In Ludwig, W.J., Krasheninnikov, V.A., et al., Init. Repts. DSDP, 71 (Pt. 1): Washington (U.S. Govt. Printing Office), 565-582.

Gombos, A.M., Jr., and Ciesielski, P.F., 1983. Late Eocene to early Miocene diatoms from the southwest Atlantic. In Ludwig, W.J., Krasheninnikov, V.A., et al., Init. Repts. DSDP, 71 (Pt. 2): Washington (U.S. Govt. Printing Office), 583-634.

Greville, R.K., 1859-1864. Descriptions of new and rare diatoms. Biblio. Phycol., Trans. Microscop. Soc. London, Ser. 1-20.

Grove, E., and Sturt, G., 1886-1887. On a fossil marine diatomaceous deposit from Oamaru, Otago, New Zealand. J. Quekett Microsc. Club, Ser. 2, 2:321-330, 3:7-12, 3:63-78, 3:131-148.

Grunow, A., 1884. Die Diatomeen von Franz-Josefs-Land. Denkschr. Kaiserl. Akad. Wiss., Wien, Mathem.-Naturw. Classe, 48:53-112.

Hajós, M., 1976. Upper Eocene and lower Oligocene Diatomaceae, Archaeomonadaceae, and Silicoflagellatae in southwestern Pacific sediments, DSDP Leg 29. In Hollister, C.D., Craddock, C., et al., Init. Repts. DSDP, 35: Washington (U.S. Govt. Printing Office), 817-883.

Hajós, M., and Stradner, H., 1975. Late Cretaceous archaeomona-daceae, diatomaceae, and silicoflagellatae from the South Pacific Ocean, Deep Sea Drilling Project, Leg 29, Site 275. In Kennett, J.P., Houtz, R.E., et al., Init. Repts. DSDP, 29: Washington (U.S. Govt. Printing Office), 9131009.

Hanna, G.D., 1927. The lowest known Tertiary diatoms in California. $J$. Paleontol., 1:103-127.

1932. The diatoms of Sharktooth Hill, Kern Country, California. Proc. Calif. Acad. Sci., Ser. 4, 29:161-263.

Hargraves, P.E., 1986. The relationship of some fossil diatom genera to resting spores. Proc, 8th Int. Diatom Symp., Paris, August, 1984, 67-80.

Harwood, D.M., 1989. Siliceous microfossils. In Barrett, P.J. (Ed.), Antarctic Cenozoic History from the CIROS-1 Drillhole, McMurdo Sound. DSIR Bull. N.Z., 245:67-97.

Harwood, D.M., and Maruyama, T., 1992. Middle Eocene to Pleistocene diatom biostratigraphy of Southern Ocean sediments from the Kerguelen Plateau, Leg 120. In Wise, S.W., Jr., Schlich, R., et al., Proc. ODP, Sci. Results, 120: College Station, TX (Ocean Drilling Program), 683-733.

Harwood, D.M., Scherer, R.P., and Webb, P.-N., 1989. Multiple Miocene marine productivity events in West Antarctica as recorded in upper 
Miocene sediments beneath the Ross Ice Shelf (Site J-9). Mar. Micropaleontol., 15:91-115.

Heiberg, P.A.C., 1863. Conspectus Criticus Diatomacearum Danicarum: Kobenhavn (Wilhelm Priors Forlag).

Heiden, H., and Kolbe, R.W., 1928. Die marinen Diatomeen der Deutschen Südpolar-Expedition 1901-1903. In von Drygalski, E. (Ed.), Deutsche Südpolar-Expedition, 1901-1903 (Vol. 8): Botanik: Berlin (Walter de Gruyter), 447-715.

Hendy, N.I., 1982. Tumulopsis fogedii gen. et spec. nov.: an unusual diatom from a South Atlantic Eocene core. Nova Hedwigia Beih., 73:275-280.

Hendy, N.I., and Sims, P.A., 1990. Some observations in variation in the valve structure of Asterolampra schmidtii Hajós, a useful stratigraphic marker for the early Oligocene. In Ouvrage dédié à H. Germain (Koeltz), 83-96.

Homann, M., 1991. Die diatomeen der Fur Formation (Alttertiär, Limfjord/ Dänemark) Geol. Jahrb. Reihe A, 123:1-285.

Hustedt, F., 1959. Die Kieselalgen Deutschlands, Österreichs und der Schweiz unter Berücksichtigung der übrigen Länder Europas sowie der angrenzenden Meeresgebiete. In Rabenhorst, L. (Ed.), Rabenhorst's Kryptogamen-Flora von Deutschland, Österreich und der Schweiz (Vol. 7) (2nd ed.): Leipzig (Akad. Verlag).

Jousé, A.P., 1955. Species novae diatomacearum aetatis palaeogenae. Botan. Mater. Otd. Sporovykh Rast., BIN, Akad. Nauk SSSR, 10:81-103.

1973. Diatoms in the Oligocene-Miocene biostratigraphic zones of the tropical areas of the Pacific Ocean. Nova Hedwigia Beih., 45:333357.

Kanaya, T., 1957. Eocene diatom assemblages from the "Kellogg" and "Sidney" shales, Mt. Diablo Area, California. Sci. Rep. Tohoku Univ., Ser. 2, 28:27-224.

Kim, W.H., and Barron, J.A., 1986. Diatom biostratigraphy of the upper Oligocene to lowermost Miocene San Gregorio Formation, Baja California Sur, Mexico. Diatom Res., 1:169-187.

Kitton, F., 1871. On diatomaceous deposits from Jutland. J. Quekett Microsc. Club, 2:88, 168-171.

Leventer, A., 1991. Sediment trap diatom assemblages from the northern Antarctic Peninsula region. Deep-Sea Res., 38:1127-1144.

Mahood, A.D., Barron, J.A., and Sims, P.A., 1993. A study of some unusual, well preserved Oligocene diatoms from Antarctica. Nova Hedwigia Beih., 106:243-267.

Miller, K.G., 1994. Middle Eocene to Oligocene stable isotopes, climate, and deep-water history: the terminal Eocene event? In Prothero, D. (Ed.), The Eocene-Oligocene Transition: New York (Columbia Univ. Press), 160177.

Miller, K.G., and Tucholke, B.E., 1983. Development of Cenozoic abyssal circulation south of the Greenland-Scotland Ridge. In Bott, M., Saxov, S., Talwani, M., and Theide, J. (Eds.), Structure and Development of the Greenland-Scotland Ridge: New Methods and Concepts: New York (Plenum), 549-590.

Moore, T.C., Jr., van Andel, T.H., Sancetta, C., and Pisias, N., 1978. Cenozoic hiatuses in the pelagic sediments. Micropaleontology, 24:113-138.

Myhre, A.M., Thiede, J., Firth, J.V., et al., 1995. Proc. ODP, Init. Repts., 151 College Station, TX (Ocean Drilling Program).

Palmer, A., 1984. Implications and biostratigraphy in the Eocene North Atlantic Ocean [Ph.D. dissert.]. Univ. of South Carolina, Columbia.

Pantocsek, J., 1886-1892. Beitrage zur Kenntnis der Fossilen Bacillarien Ungarns (Vols. 1-3): Berlin (W. Junk).

Prichard, A., 1861. A History of Infusoria, Living and Fossil: London (Whittaker and Co.).

Proschkina-Lavrenko, A.I., 1949. Diatom Analysis: Handbook of Fossil and Recent Diatoms, Order Centrales. Bot. Inst., V.L. Komarova, Akad. Nauk SSSR. (in Russian)
Round, F.E., Crawford, R.M., and Mann, D.G., 1990. The Diatoms: Biology and Morphology of the Genera: Cambridge (Cambridge Univ. Press).

Rubina, H.V., 1962. New Melosira species from Turtass strata of the Western Siberian lowlands. Tr. Sibirskogo Nii Geol., Geophis. Mineral. Resours., 23:104-107. (in Russian)

1968. Diatom assemblages in sediments of the Turtass strata of the Western Siberian lowlands. In Fossil Diatoms of the USSR: Moscow (Nauka), 61-66. (in Russian)

Scherer, R.P., 1994. A new method for the determination of absolute abundance of diatoms and other silt-sized sedimentary particles. J. Paleolimn., 12:171-180.

Schmidt, A., 1874, 1878, 1888, 1890, 1892, 1893. In Schmidt, A., et al., Atlas der Diatomaceenkunde: Leipzig (O.R. Reisland).

Schrader, H.-J., 1969. Die pennaten Diatomeen aud dem Obereozän von Omaru, Neuseeland. Nova Hedwigia Beih., 28:1-124.

1976. Cenozoic planktonic diatom biostratigraphy of the Southern Pacific Ocean. In Hollister, C.D., Craddock, C., et al., Init. Repts. DSDP, 35: Washington (U.S. Govt. Printing Office), 605-671.

Schrader, H.-J., and Fenner, J., 1976. Norwegian Sea Cenozoic diatom biostratigraphy and taxonomy. In Talwani, M., Udintsev, G., et al., Init. Repts. DSDP, 38: Washington (U.S. Govt. Printing Office), 921-1099.

Sheshukova-Poretzkaya, V.S., 1962. Novie I redkie Bacillariophyta iz diatomovoi sviti Sakhalin. (New and rare Bacillariophyta from diatom series of Sakhalin Island.) Uch. Zap., Igu. Ser. Biol. Nauk (Leningrad Univ.), 49:203-211.

Sims, P.A., 1994. Skeletonemopsis, a new genus based on the fossil species of the genus Skeletonema. Diatom Res., 9:387-410.

Sims, P.A., and Ross R., 1988. Some Cretaceous and Palaeogene Trinacria (diatom) species. Bull. Brit. Mus. (Nat. Hist.), Bot. Ser., 18:275-322.

Strelnikova, N.I., 1960. Diatomoovye vodorosli I kremneveye zhgutikovye iz paleogenovyh otozhenij Obsko-purskogo mezhdyrechya. Paleophytol. Sbornok, Nedra, Tr. VNIGRI, 158:33-45.

Strelnikova, N.I., 1964. New species of diatoms from upper Cretaceous deposits of the Synya River Basin (Western Siberia). Paleophytol. Sbornok, Nedra, Tr. VNIGRI, 239:229-323. (in Russian)

Takano, H., 1982. New and rare diatoms from Japanese marine waters, VIII Bull. Tokai Reg. Fish. Res. Lab., 106:45-62.

Tynni, R., 1982. The Reflection of Geological Evolution in Tertiary and Interglacial Diatoms and Silicoflagellates in Finnish Lapland. Geol. Surv. Finland, 320.

Van Heurck, H., 1880, 1882. Synopsis des Diatomées de Belgique. Atlas (1880-1881): Anvers (Ducaju et Cie)

, 1896. A Treatise on the Diatomaceae. London (William Wesley \& Son).

Williams, D.M., 1989. Cavitatus Williams nov, gen.: a new genus of fossil diatom (Bacillariophyta) based on Synedra jouseana SheshukovaPoretskaya. Rev. Palaeobot. Palynol. 58:357-362.

Witt, O.N., 1885. Ueber den Polierschiefer von Archangelsk-Kurojedowo im Gouv. Simbirsk. Verhandl. Russisch-Kaiserlichen Mineral. Gesell. St. Petersburg. 2. Ser., 22:137-177.

Yanagisawa, Y., and Suzuki, Y., 1987. Diatoms and silicoflagellates from the Oligocene Shirasaka Formation of the Joban Coalfield, northeast Japan. Bull. Geol. Surv. Jpn. [Chishitsu Chosasho Geppo], 38:81-98.

Date of initial receipt: 28 July 1995

Date of acceptance: 18 December 1995

Ms 151SR-155 


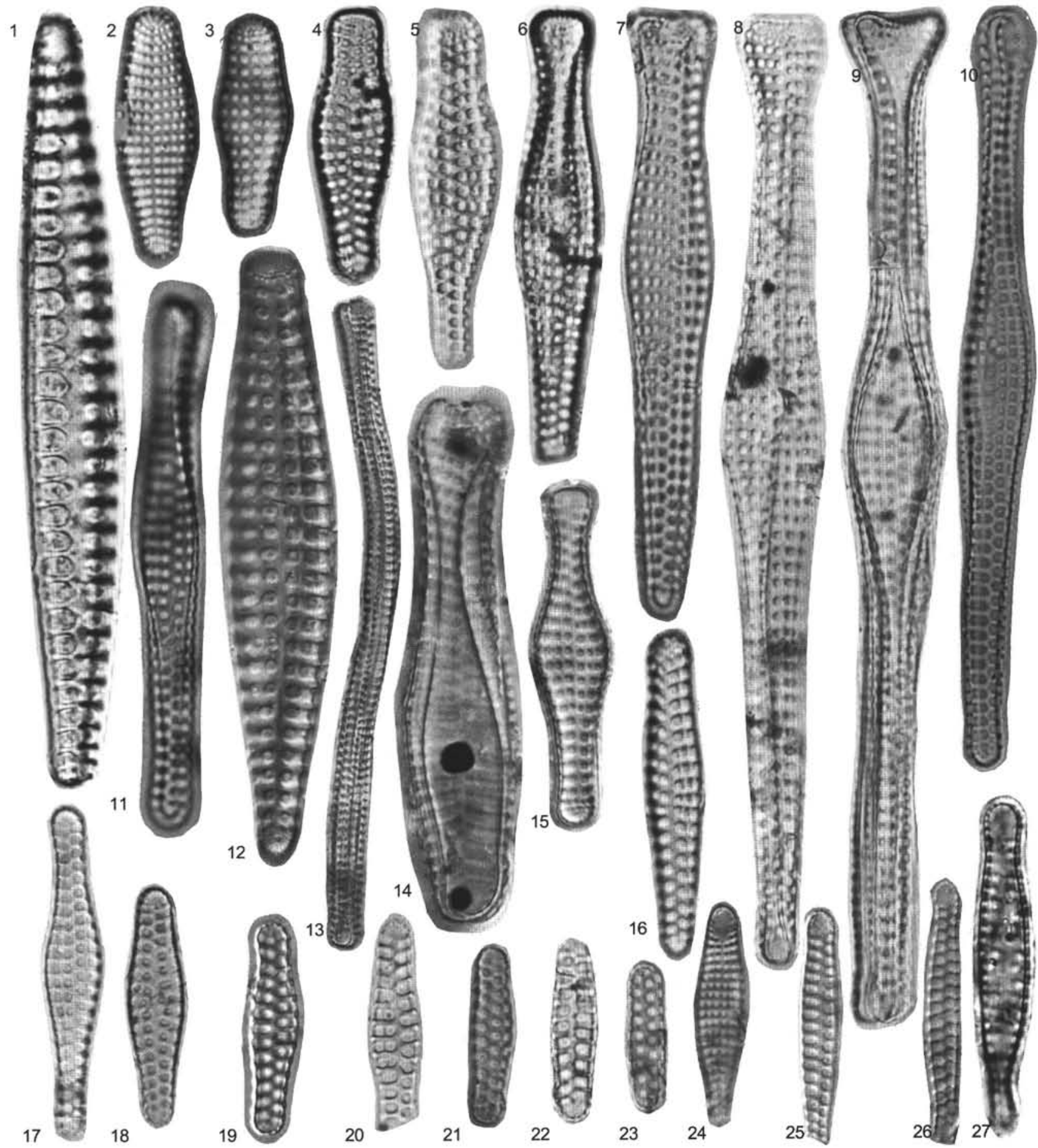

Plate 1. Paleogene diatoms, magnification $1425 \times$ unless otherwise indicated. 1. Grunoviella gemmata, Sample 151-908A-34X-2, 8-9 cm. 2. Sceptroneis fennerae?, Sample 151-908A-32X-3, 88-89 cm. 3. Sceptroneis fennerae, Sample 151-908A-30X-2, 6-7 cm. 4. Sceptroneis fennerae, Sample 151-908A-25X-CC, holotype. 5. Sceptroneis fennerae, Sample 151-908A-24X-CC. 6. Sceptroneis fennerae, Sample 151-908A-26X-3, 90-91 cm. 7. Sceptroneis humuncia var. rondipoda, holotype. Sample 151-908A-25X-CC. 8. Sceptroneis humuncia var. rondipoda, Sample 151-908A-26X-3, 90-91 cm. 9. Sceptroneis humuncia var. rondipoda, Sample 151-908A-21X-3, 3-4 cm. 10. Sceptroneis praecaducea, note twist in the valve, Sample 151-908A-21X-5, 75-76 cm. 11. Sceptroneis praecaducea, note twist, Sample 151-908A-21X-5, 75-76 cm. 12. Sceptroneis sp., Sample 151-908A-32X-3, 88-89 cm. 13. Sceptroneis tenue, Sample 151908A-26X-3, 90-91 cm, 950x. 14. Sceptroneis affn. humuncia var. rondipoda (tetralogical form), Sample 151-908A-26X-3, 90-91 cm. 15. Sceptroneis fennerae, Sample 151-908A-X-4, 3-4 cm. 16. Sceptroneis praecaducea, Sample 151-908A-24X-CC. 17. Sceptroneis praecaducea, Sample 151-908A-27X-5, 44$45 \mathrm{~cm}$. 18. Sceptroneis pupa/grunowii transitional form, Sample 151-908A-21X-3, 3-4 cm. 19. Sceptroneis pupa/grunowii transitional form, Sample 151908A-21X-3, 3-4 cm. 20. Sceptroneis pupalgrunowii transitional form, Sample 151-908A-21X-3, 3-4 cm. 21. Sceptroneis pupa/grunowii transitional form, Sample 151-908A-25X-CC. 22. Sceptroneis pupa, Sample 151-908A-21X-3, 30-31 cm. 23. Sceptroneis pupa, Sample 151-908A-21X-3, 30-31 cm. 24. Sceptroneis sp., Sample 151-908A-25X-CC. 25. Sceptroneis grunowii, Sample 151-913B-25X-CC. 26. Sceptroneis grunowii, Sample 151-913B-26R-3, 4-5 cm. 27. Sceptroneis mayenica, Sample 151-913B-26R-3, 4-5 cm. 


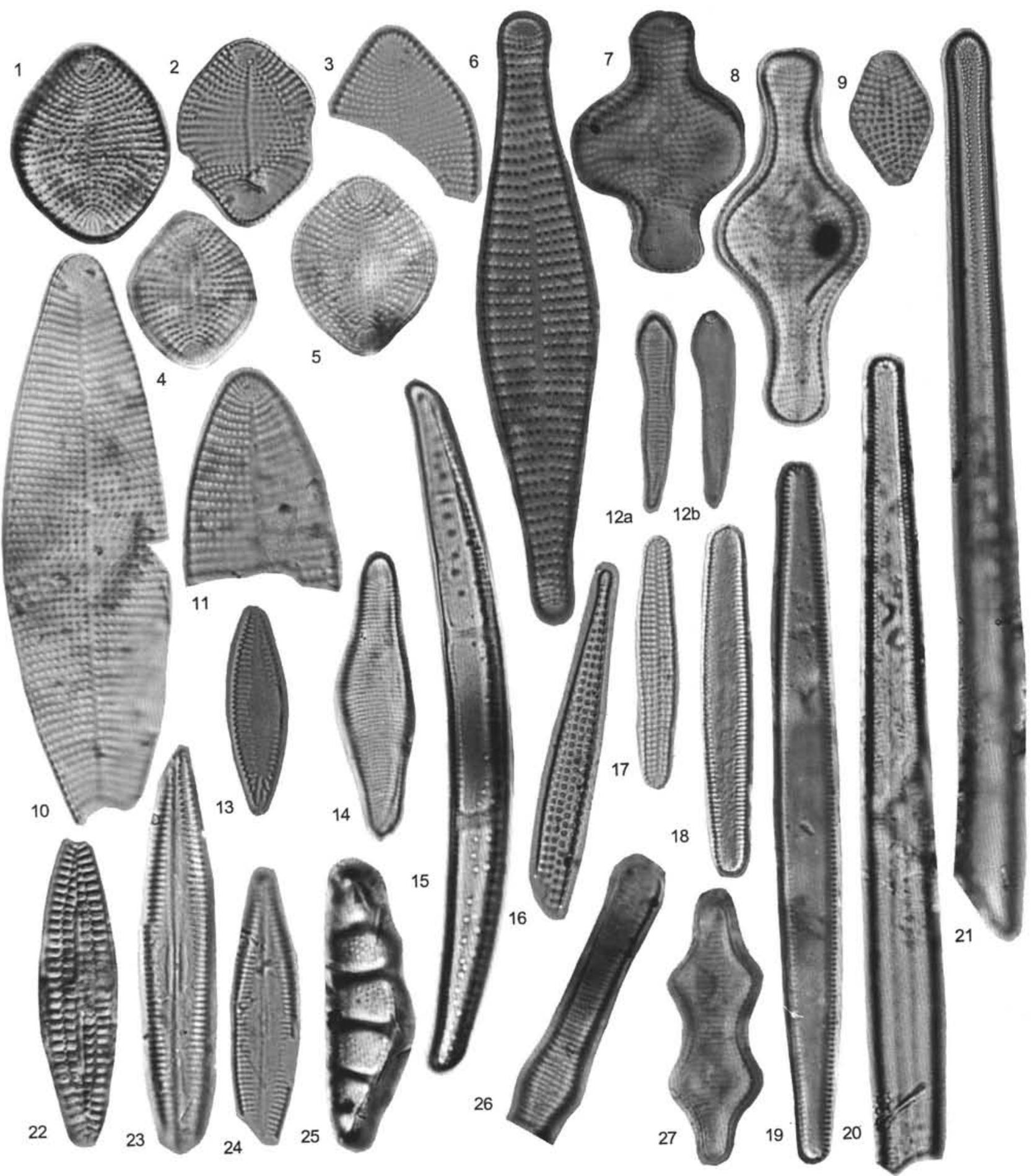

Plate 2. Paleogene diatoms, magnification 1425x unless otherwise indicated. 1. "Detonia?" sp. A, Sample 151-908A-29X-5, 12-13 cm. 2. "Detonia?" sp. A, Sample 151-908A-29X-CC. 3. "Detonia?" sp. A, Sample 151-908A-29X-5, 122-123 cm. 4. “Detonia?" sp. A, Sample 151-908A-24X-CC. 5. "Detonia?" sp. A, Sample 151-908A-21X-3, 3-4 cm. 6. Sceptroneis propinqua, Sample 151-908A-31X-CC. 7. Rhaphoneis sp. A, Sample 151-908A-31X-1, 8-9 cm. 8. Rhaphoneis sp. A, Sample 151-908A-21X-3, 30-31 cm. 9. Rhaphoneis angulata, Sample 151-908A-31X-1, 8-9 cm. 10. "Detonia?" sp. B, Sample 151-908A-29XCC. 11. "Detonia?" sp. B, Sample 151-913B-24R-CC. 12a, b. Kannoa sp., two levels of focus, Sample 151-908A-24X-CC. 13. "Synedra?" sp. 1, Sample 151913B-24R-CC. 14. Grammatophora sp., Sample 151-908A-29X-CC. 15. Drepanotheca bivittata, Sample 151-908A-21X-5, 75-76 cm. 16. Sceptroneis sp., Sample 151-908A-23X-CC. 17. Neodelphineis pelagica, Sample 151-908A-24X-CC. 18. Cavitatus jouseanus, Sample 151-908A-23X-CC. 19. Cavitatus jouseanus, Sample 151-908A-32X-7, 46-47 cm. 20. Cavitatus jouseanus, Sample 151-908A-31X-1, 8-9 cm. 21. Clavicula polymorpha, Sample 151-913B-24R-CC, magnification 950×. 22. Rouxia sp. A, Sample 151-908A-31X-CC. 23. Navicula udintsevii, Sample 151-913B-24R-CC. 24. Navicula udintsevii, Sample 151913B-25R-CC. 25. Eunotogramma sp., Sample 151-908A-X-2, 6-7 cm. 26. "Fragilaria" sp. A, Sample 151-908A-34X-3, 85-86 cm. 27. "Fragilaria" miocenica, Sample 151-908A-32X-7, 46-47 cm. 


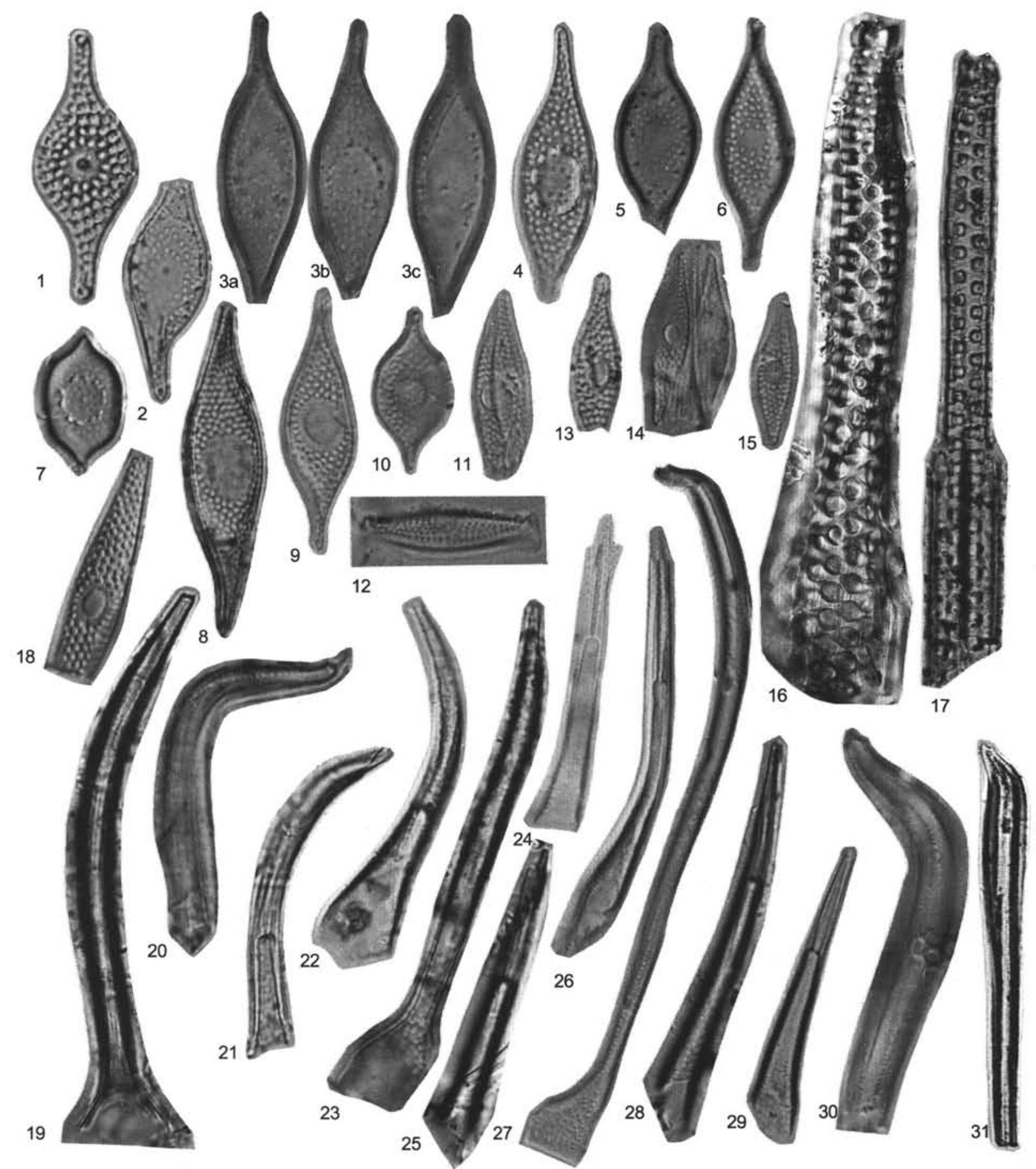

Plate 3. Paleogene diatoms, magnification 1350x unless otherwise indicated. 1. Rutilaria areolata, Sample 151-908A-25X-CC. 2. Cymatosira praecompacta, Sample 151-908A-29X-CC. 3a, b, c. Cymatosira praecompacta, vertical focus through three attached valves, demonstrating the considerable polymorphy in this genus, Sample 151-908A-31X-CC. 4. Cymatosira praecompacta, Sample 151-908A-31X-1, 8-9 cm. 5. Cymatosira praecompacta, Sample 151-908A31X-CC. 6. Cymatosira praecompacta, Sample 151-908A-31X-CC. 7. Cymatosira compacta, Sample 151-908A-31X-1, 8-9 cm. 8. Praecymatosira sp., Sample 151-913B-26R-7, 17-19 cm. 9. Cymatosira praecompacta, Sample 151-908A-29X-CC. 10. Cymatosira praecompacta, Sample 151-908A-31X-CC. 11. Cymatosira praecompacta, Sample 151-908A-32X-5, 94-95 cm. 12. Cymatosira praecompacta, Sample 151-908A-32X-5, 94-95 cm. 13. Cymatosira praecompacta, Sample 151-908A-32X-5, 94-95 cm. 14. Cymatosira sp. A, Sample 151-913B-24R-CC. 15. Cymatosira sp. A, Sample 151-913B-24R-CC. 16. Cymatosira sp. A, Sample 151-913B-24R-CC. 17. Pyxilla oligocaenica, Sample 151-908A-27X-5, 44-45 cm, magnification 900x. 18. Pyxilla oligocaenica var. tenuis, Sample 151-908 21X-3, 30-31 cm, magnification 900×. 19. "Rhizosolenia?" pokrovskayae, Sample 151-908A-23X-5, 2-3 cm. 20. "Rhizosolenia?" sp. A, Sample 151-908A-29X-5, 122-123 cm. 21. Rhizosolenia oligocaenica var. A, Sample 151-908A-21X-3, 30-31 cm. 22. Rhizosolenia oligocaenica var. A, Sample 151-908A-24X-4, 90-91 cm. 23. Monobrachia? sp., Sample 151-913B-24R-CC. 24. Rhizosolenia oligocaenica var. styliforma, Sample 151-908A$21 \mathrm{X}-3,30-31 \mathrm{~cm}$, holotype. 25. Rhizosolenia oligocaenica var. styliforma, Sample 151-908A-21X-3, 30-31 cm. 26. Rhizosolenia oligocaenica var. styliforma, Sample 151-908A-21X-3, 30-31 cm. 27. Monobrachia unicornuta, Sample 151-913B-24R-CC. 28. Rhizosolenia oligocaenica, Sample 151-908A-21X-5, 75$76 \mathrm{~cm}$. 29. Rhizosolenia oligocaenica, Sample 151-908A-21X-5, 75-76 cm. 30. "Rhizosolenia?" sp. A, Sample 151-908A-30X-2, 6-7 cm. 31. Riedelia? claviger?, Sample 151-908A-33X-CC, 900× magnification. 


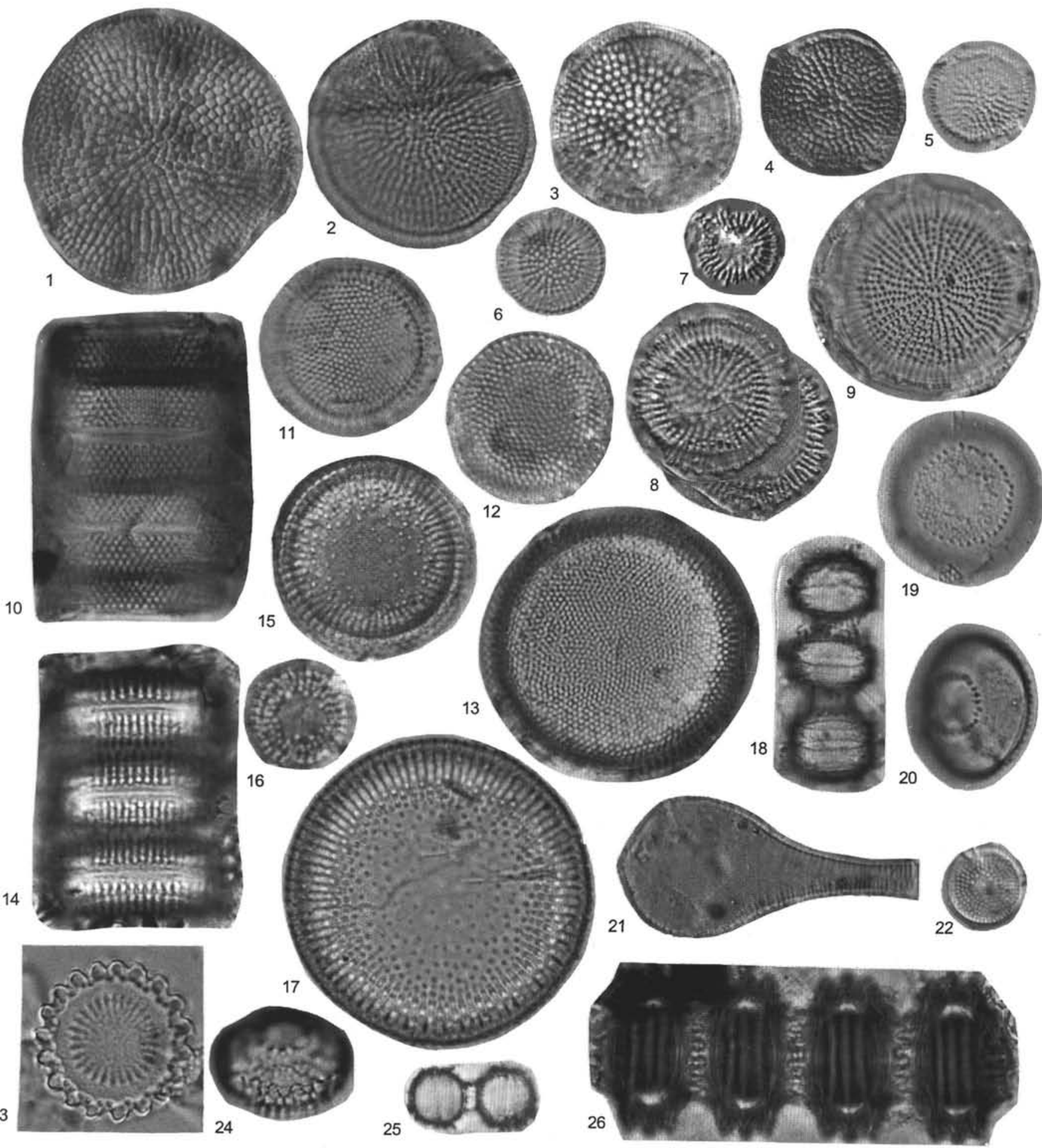

Plate 4. Paleogene diatoms, magnification $1500 \times$ unless otherwise indicated. 1. Thalassiosira nansenii $\mathrm{n}$. sp., Sample 151-908A-32X-3, 88-89 cm. 2. Thalassiosira nansenii $\mathrm{n}$. sp., Sample 151-908A-21X-5, 75-76 cm. 3. Thalassiosira nansenii $\mathrm{n}$. sp., Sample 151-908A-30X-4, 3-4 cm. 4. Thalassiosira nansenii $\mathrm{n}$. sp., Sample 151-908A-26X-3, 90-91 cm, holotype. 5. Thalassiosira nansenii n. sp., Sample 151-908A-29X-5, 122-123 cm. 6. Thalassiosira dubiosa/mediaconvexa, Sample 151-913B-26R-3, 4-5 cm. 7. Thalassiosira dubiosa, Sample 151-913B-25R-CC. 8. Thalassiosira mediaconvexa, Sample 151-913B-26R-3, 4-5 cm. 9. Thalassiosira mediaconvexa, Sample 151-913B-26R-3, 4-5 cm. 10. Melosira ignota, Sample 151-908A-31X-1, 8-9 cm. 11. Melosira ignota, Sample 151-908A-31X-1, 8-9 cm. 12. Melosira ignota, Sample 151-908A-32X-3, 88-89 cm. 13. Melosira ignota, Sample 151-908A-31X-CC. 14. Distephanosira architecturalis, Sample 151-913B-24R-CC. 15. Distephanosira architecturalis, Sample 151-908A-34X-3, 8-9 cm. 16. Distephanosira architecturalis, Sample 151-913B-24R-CC. 17. Distephanosira architecturalis, Sample 151-913B-25R-5, 49-50 cm. 18. Trochosira spinosa, Sample 151-908A-21X-3, 30-31 cm. 19. Trochosira spinosa, Sample 151-908A-24X-CC. 20. Trochosira spinosa, Sample 151-908A-21X-3, 30-31 cm. 21. Licmophora? sp., Sample 151-908A-26X-3, 90-91 cm. 22. Trochosira coronata, Sample 151-913B-25R-CC. 23. Paralia crenulata, Sample 151-908A-24X-CC. 24. Paralia crenulata, Sample 151-908A21X-5, 75-76 cm. 25. Trochosira coronata, Sample 151-913B-25R-CC. 26. "Skeletonema" utriculosa, Sample 151-908A-31X-CC. 


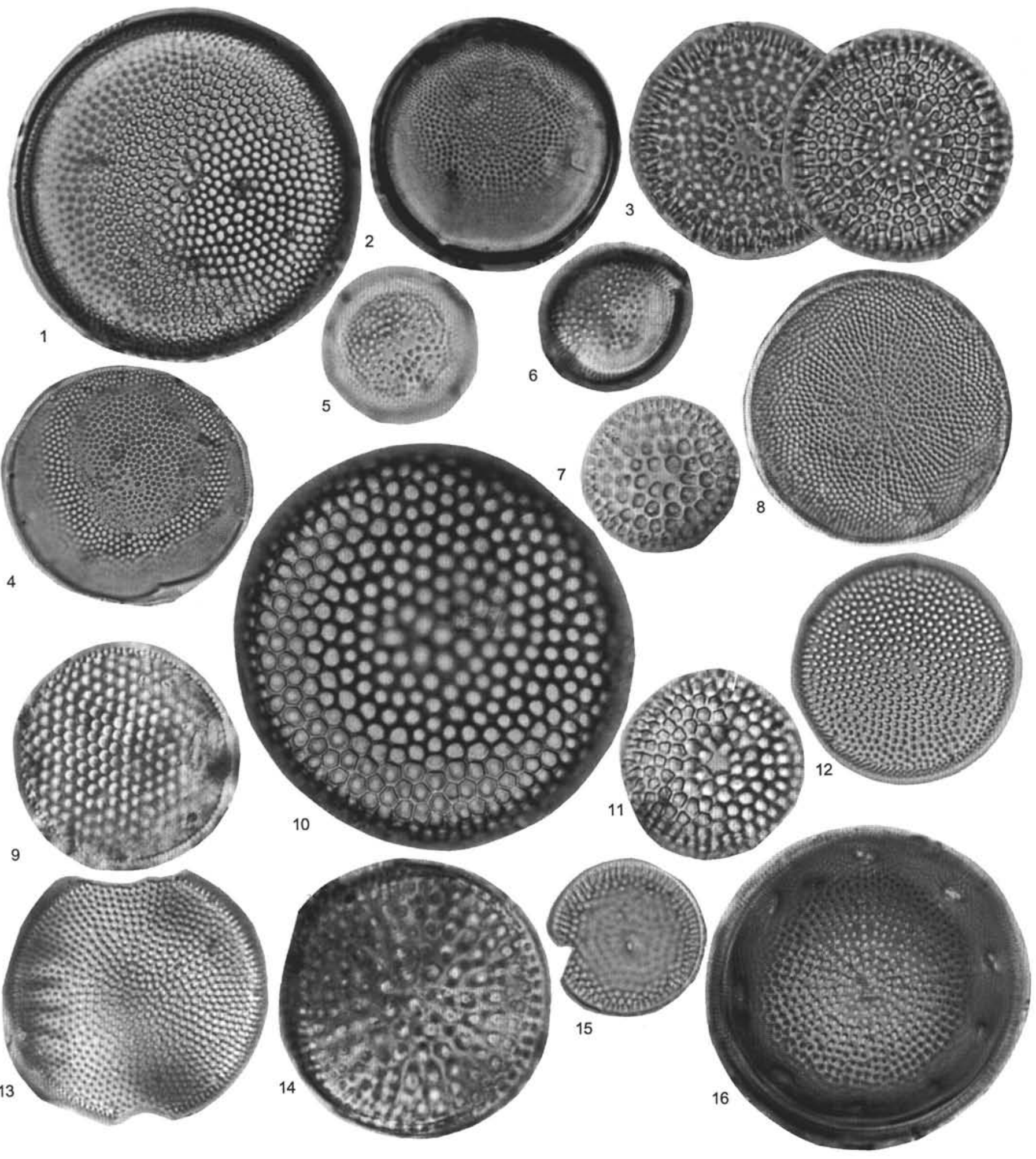

Plate 5. Paleogene diatoms, magnification 1500x unless otherwise indicated. 1. Azpeitia tuberculata var. atlantica, Sample 151-908A-26X-3, 90-91 cm. 2. Cestodiscus sp. A, Sample 151-908A-33X-3, 4-5 cm. 3. Cestodiscus pulchellus var. novazealandica, Sample 151-908A-26X-3, 90-91, cm, magnification, 1000X. 4. Cestodiscus sp. B, Sample 151-908A-34X-3, 85-86 cm. 5. Cestodiscus sp. B, Sample 151-908A-29X-5, 122-123 cm. 6. Azpeitia oligocaenica, Sample 151908A-21X-CC, magnification 1000×. 7. Cestodiscus sp. C, Sample 151-908A-34X-3, 85-86 cm. 8. Cestodiscus sp. A, Sample 151-913B-24R-CC. 9. Thalassiosira sp. A (note focus on strutted processes), Sample 151-908A-27X-5, 44-45 cm. 10. Craspedodiscus? sp., Sample 151-908A-31X-1, 8-9 cm, magnification 800x. 11. Cestodiscus sp. C, Sample 151-908A-29X-5, 122-123 cm. 12. Cestodiscus sp. A?, Sample 151-913B-24R-CC. 13. Cestodiscus sp. A, Sample 151913B-24R-CC. 14. Stictodiscus nitidus, Sample 151-908A-26X-3, 90-91 cm. 15. Thalassiosira sp. B, Sample 151-913B-25R-CC. 16. Actinocyclus ehrenbergii group (note pseudonodulus and labiate processes, accentuated by a trapped bubble), Sample 151-908A-32X-5, 94-95 cm. 


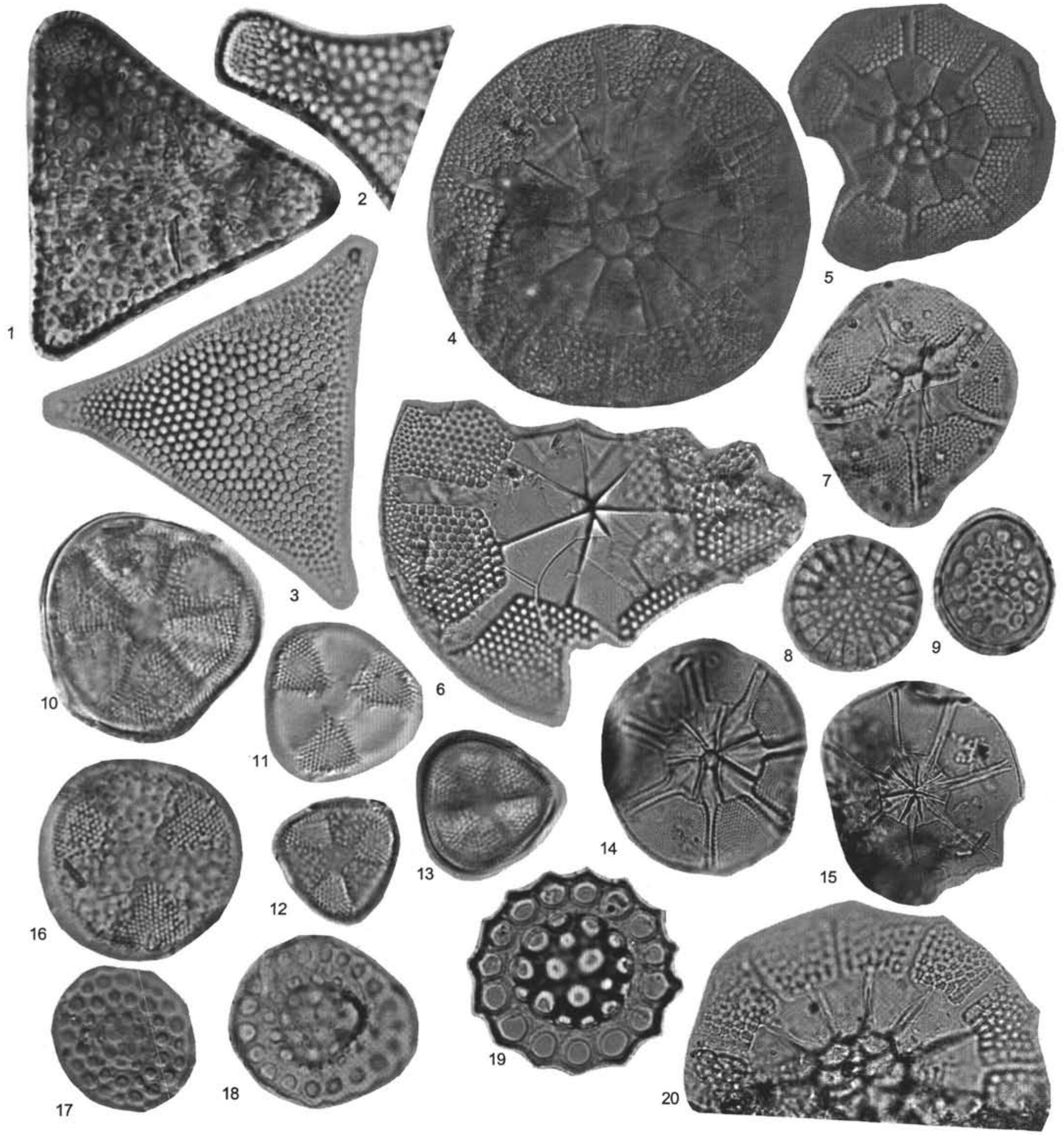

Plate 6. Paleogene diatoms, magnification $1500 \times$ unless otherwise indicated. 1. Eurossia irregularis, Sample 151-908A-32X-3, 88-89 cm. 2. Eurosia irregularis var. incurvatus, (apex) Sample 151-908A-27X-5, 44-46 cm. 3. Pseudotriceratium radiosoreticulatum, Sample 151-908A-21X-3, 30-31 cm. 4. Asterolampra insignis, Sample 151-913B-24R-CC, magnification 750x. 5. Asterolampra affinis, Sample 151-913B-24R-CC, magnification 500×. 6. Asteromphalus symmetricus?, Sample 151-913B-24R-CC. 7. Asteromphalus flabellatus, Sample 151-908A-27X-5, 44-45 cm. 8. Pseudostictodiscus picus, Sample 151-913B24R-CC. 9. Macrora barbadensis, Sample 151-908A-25X-CC. 10. Actinoptychus irregularis, Sample 151-913B-24R-CC. 11. Actinoptychus irregularis, Sample 151-913B-24R-CC. 12. Actinoptychus irregularis, Sample 151-913B-25R-CC. 13. Actinoptychus irregularis, Sample 151-913B-24R-CC. 14. Asteromphalus oligocenicus, Sample 151-908A-23X-CC, magnification 600x. 15. Asterolampra punctifera, Sample 151-913B-24R-CC, magnification 600x. 16. Actinoptychus undulatus, Sample 151-908A-25X-CC. 17. Macrora barbadensis, Sample 151-908A-31X-1, 8-9 cm. 18. Macrora barbadensis, Sample 151908A-31X-CC. 19. Macrora stella, Sample 151-908A-29X-CC. 20. Asterolampra insignis, Sample 151-913B-25R-CC. 


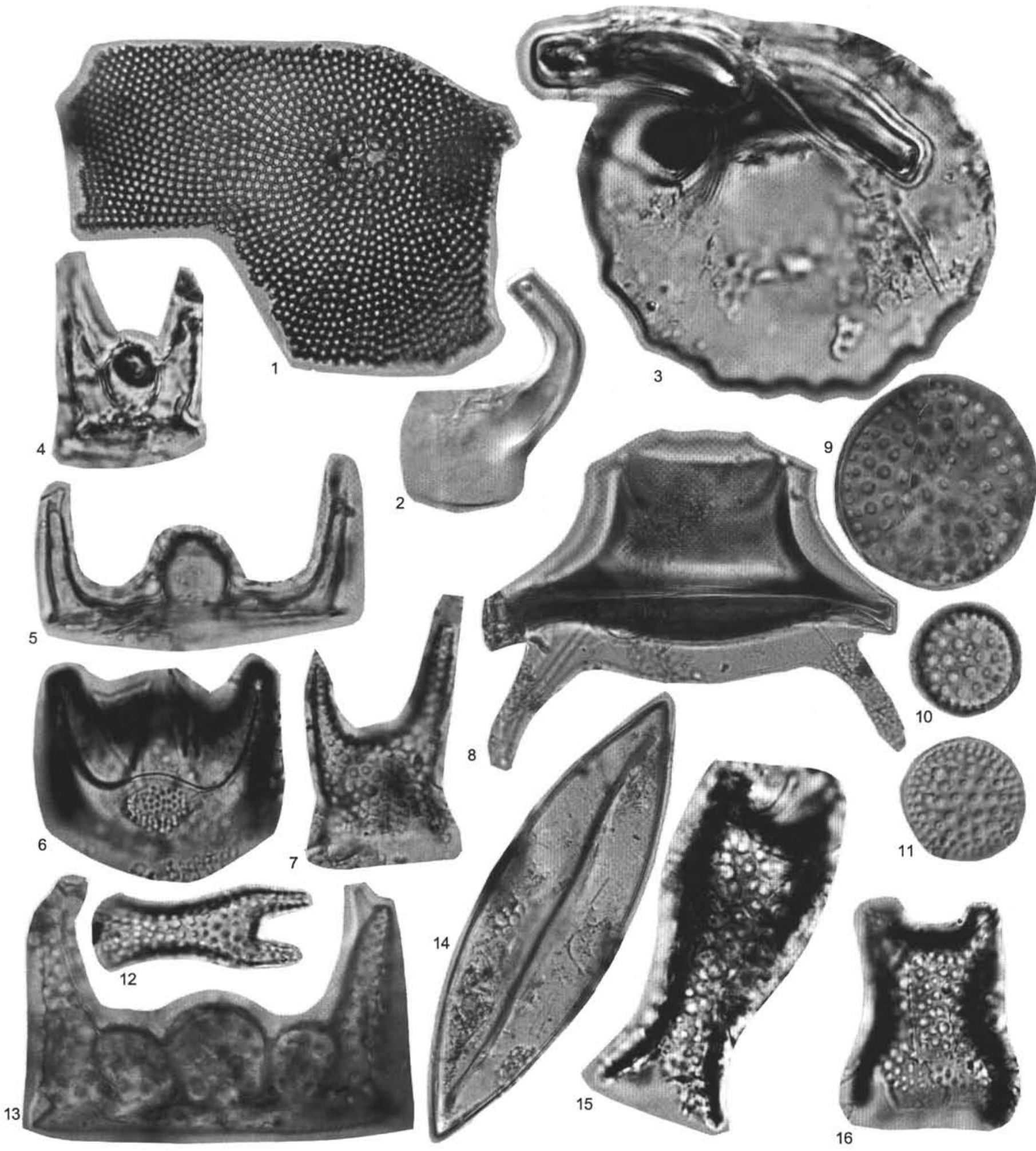

Plate 7. Paleogene diatoms, magnification $1500 \times$ unless otherwise indicated. 1. Coscinodiscus affn. tenerrimus, Sample 151-913B-24R-CC, magnification $1000 \times$. 2. Tubaformis cf. unicornis, single tube (note large labiate process), Sample 151-913B-25R-CC, magnification 1000×. 3. Tubaformis cf. unicornis, Sample 151-913B-25R-CC. 4. Hemiaulus horridus group, Sample 151-908A-25R-CC. 5. Hemiaulus horridus group, Sample 151-908A-X-2, 6-7 cm. 6. Hemiaulus elegans, Sample 151-908A-25X-CC. 7. Hemiaulus incisus, Sample 151-908A-32X-3, 88-89 cm. 8. Odontotropis carinifera, Sample 151-913B-25R-CC, magnification 750×. 9. Rocella praenitida, Sample 151-908A-X-2, 6-7 cm. 10. Rocella praenitida, Sample 151-908A-21X-3, 30-31 cm. 11. Rocella praenitida, Sample 151-908A-32X-3, 88-89 cm. 12. Hemiaulus incisus, Sample 151-913B-26R-3, 4-5 cm. 13. Hemiaulus polycistinorum, Sample 151-908A-24X-CC. 14. Odontotropis carinifera, (epitheca), Sample 151-913B-25R-CC, magnification 1000x. 15. Hemiaulus affn. incisus?, Sample 151-913B-26R-3, 4-5 cm. 16. Hemiaulus affn. incisus?, Sample 151-913B-25R-CC. 


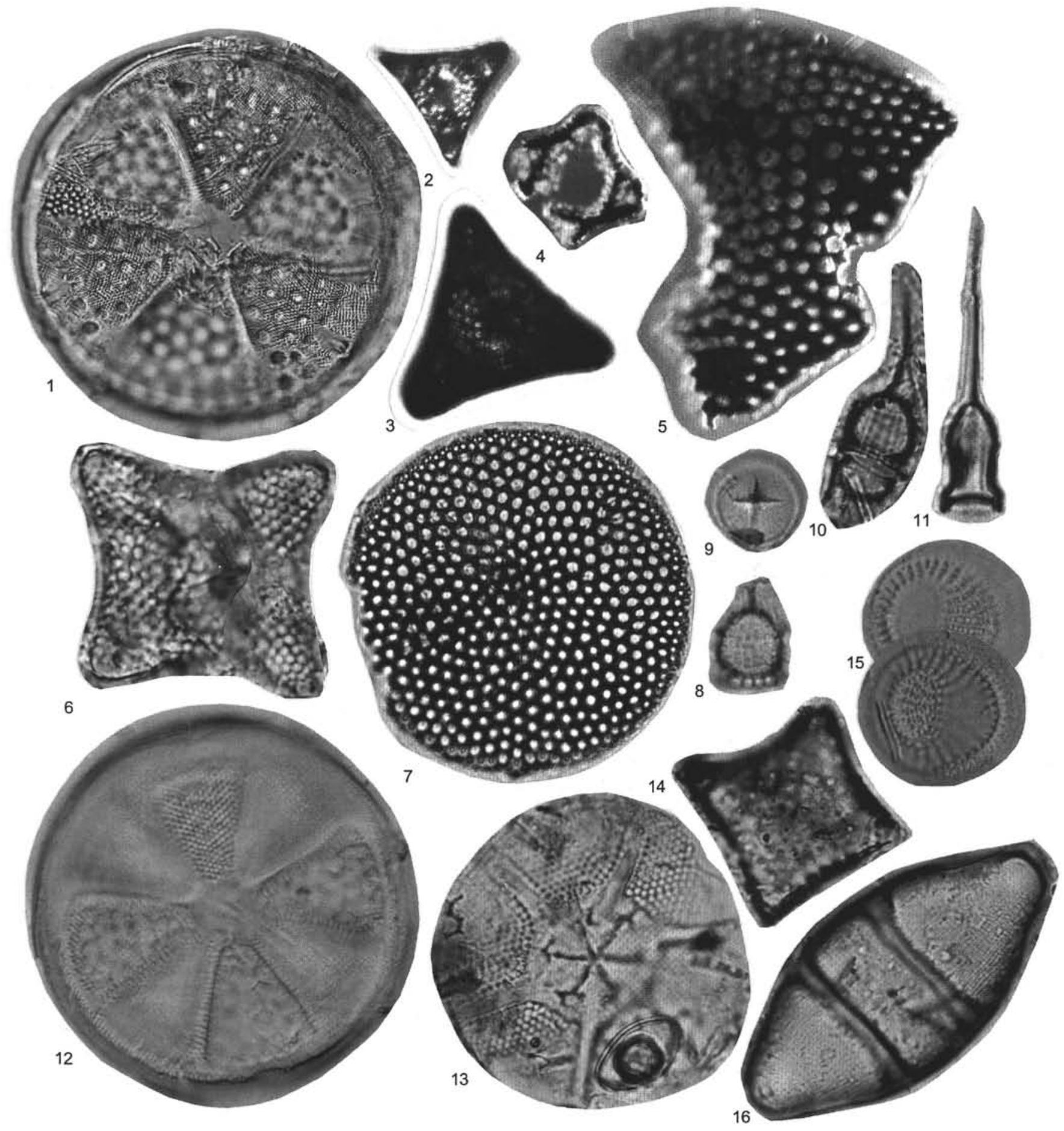

Plate 8. Paleogene diatoms, magnification $1500 \times$ unless otherwise indicated. 1. Actinoptychus sp. A, Sample 151-913B-24R-CC, magnification 750x. 2. Triceratium sp., (pyritized) Sample 151-913B-32R-CC. 3. Triceratium sp., (pyritized) Sample 151-913B-32R-CC. 4. Triceratium inconspicuum, (pyritized) Sample 151-913B-32R-CC. 5. Brightwellia sp., (pyritized) Sample 151-913B-32R-CC, magnification 750×. 6. Amphitetras sp., Sample 151-913B-26R-7, $17-19$ cm. 7. Coscinodiscus oligocenicus, Sample 151-913B-25R-CC, magnification 750×. 8. Costopyxis trochlea, Sample 151-913B-24R-CC. 9. Costopyxis trochlea, Sample 151-913B-25R-CC. 10. Costopyxis trochlea, Sample 151-913B-25R-5, 49-50 cm. 11. Pterotheca aculeifera, Sample 151-913B-26R-3, 4-5 cm. 12. Actinoptychus delicatissimus, Sample 151-908A-31X-1, 8-9 cm, magnification 1000×. 13. Asteromphalus? affn. symmetricus?, Sample 151-908A-27X-5, 44-45 $\mathrm{cm}$. 14. Trinacria cornuta, Sample 151-908A-32X-5, 2-3 cm, small, reworked specimen. 15a, b. Cyclotella sp. A, Sample 151-908A-31X-1, 8-9 cm. 16. Anaulus sp., Sample 151-908A-32X-3, 88-89 cm. 